\title{
Ovarian carcinoma and serous effusions. Changing views regarding tumor progression and review of current literature ${ }^{1}$
}

\author{
Ben Davidson * \\ Department of Pathology, The Norwegian Radium \\ Hospital, University of Oslo, Montebello \\ N-0310 Oslo, Norway
}

Received October 2001

Accepted 26 November 2001

Carcinoma of the ovary is the leading cause of death from gynecological cancer in western countries. Ovarian carcinoma is commonly associated with the accumulation of fluid containing malignant cells in the peritoneal, and not infrequently in the pleural cavity. The differentiation of these cells from reactive mesothelial cells is at times difficult. In addition, tumor progression in ovarian carcinoma and the biological characteristics of carcinoma cells in effusions compared to their counterparts in solid tumors are poorly understood. This review details the current knowledge regarding diagnostic and biologic aspects of effusion cytology, with emphasis on ovarian carcinoma. Results from our first studies of effusions are subsequently presented. These attempt to address several issues. First, to improve the diagnostic ability to detect cancer cells in effusions using antibodies designed for the differentiation of epithelial cells from mesothelial cells. Secondly, to study genotypic and phenotypic differences between ovarian carcinoma cells in effusions, solid primary tumors and metastatic lesions, as well as to compare malignant cells in peritoneal and pleural effusions. These studies of carbohydrate antigens, E-cadherin complex and matrix metalloproteinases (MMP) attempted to evaluate whether ovarian carcinoma cells in effusions possess true metastatic properties, or are similar to the cells in primary tumors, thereby merely representing the result of a shedding process. Finally, the prognostic role of these molecules was studied in solid tumors

\footnotetext{
${ }^{1}$ This study was supported by grant D-01086 from the Norwegian Cancer Society.

${ }^{*}$ Correspondence, galley proofs and reprint requests: Dr. Ben Davidson, Department of Pathology, The Norwegian Radium Hospital, Montebello N-0310 Oslo, Norway. Tel.: +47 229348 71; Fax: +47 225085 54; E-mail: bend@ulrik.uio.no.
}

from a patient cohort consisting of long- and short-term survivors, followed for up to 20 years.

Figure 1 on http://www.esacp.org/acp/2001/23-3_4/david. son.htm

\section{Introduction}

\subsection{Carcinoma of the ovary}

Carcinoma of the ovary is the leading cause of death from gynecological cancer in the United States [1], causing the death of approximately 15,000 women every year. The incidence of this disease is comparable in other western countries [2], among them the Scandinavian countries [3]. In Norway approximately 450 new cases are diagnosed every year, and the incidence of the disease is on the rise [3]. Ovarian carcinomas are often asymptomatic in the early stages of their growth. In a large international study, $64 \%$ of the patients presented with stage III or IV disease [4]. Despite the introduction of chemotherapeutic regimes as adjunct to surgery, the 5-year survival of ovarian carcinoma remains at $35 \%$, being $20 \%$ for serous carcinomas, the most common histologic subtype [5,6].

\subsubsection{Embryology}

Surface epithelial tumors of the ovary account for more than $60 \%$ of all ovarian tumors, and for almost $90 \%$ of the malignant ovarian neoplasms in the western world [5,7]. Most of these tumors are believed to derive from the coelomic surface epithelium covering the ovary. The latter is continuous with the coelomic epithelium that penetrates the early gonad to form the Müllerian duct. This common embryonic origin is reflected in the various differentiation pathways of ovarian tumors in the adult [7]. In the reproductive period, and more so in the post-menopausal period, extensions of the surface epithelium form epithelial inclusions, which become cystic. Epithelial tumors arise most often from these inclusions, accounting for the dominant cystic appearance of many of these tumors [7]. 

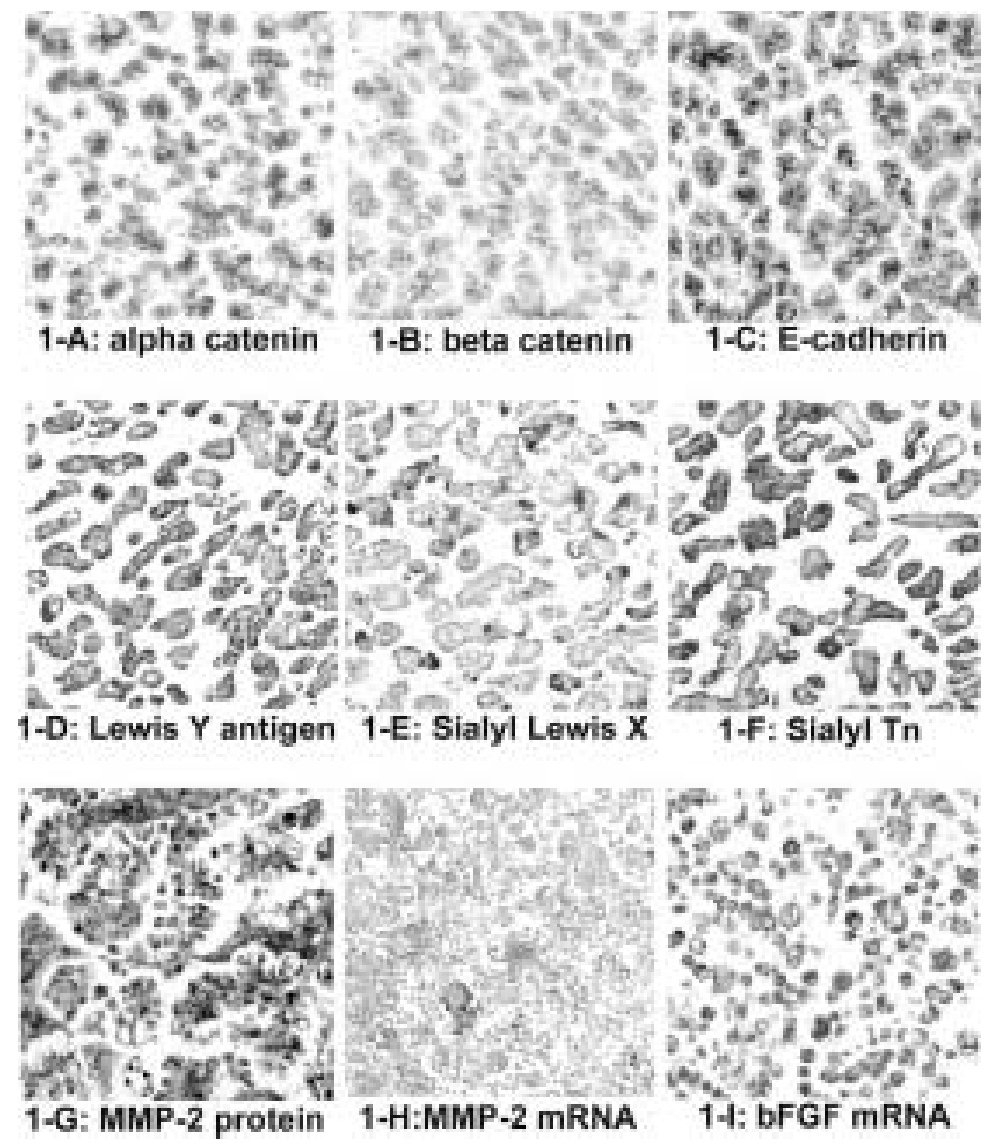

Fig. 1. Expression of metastasis-associated molecules in ovarian carcinoma cells in effusions. Figures 1-A to 1-C: Protein expression of E-cadherin complex molecules. Figures 1-D to 1-F: Carbohydrate antigen expression. Figure 1-G: Protein expression of the protease matrix metalloproteinase-2 (MMP-2). Figure 1-H: mRNA MMP-2 expression. Figure 1-I: mRNA expression of the angiogenic molecule basic fibroblast growth factor (bFGF). This figure can be viewed in full colour on: http://www.esacp.org/acp/2001/23-3_4/davidson.htm.

\subsubsection{Classification}

Ovarian carcinomas are classified according to four criteria, namely cell type, the pattern of growth, the presence or absence of a stromal component and the degree and character of proliferation in the neoplastic cells [7]. Epithelial tumor cell types comprise (WHO classification, 1995): Serous, mucinous, endometrioid, clear cell, transitional, squamous, combined and undifferentiated. The pattern of growth is defined as exophytic, endophytic, or both. The component of proliferating ovarian stroma is minor in most ovarian tumors, with the exception of the benign Brenner tumor. The degree and character of proliferation give rise to the division of epithelial tumors into benign, borderline and malignant tumors. Benign tumors (cystadenomas) appear in all ages, most often in the fifth decade. They have a higher incidence than their malignant counterparts, comprising $70 \%$ of all serous tumors, the most common histologic type [7]. These tu- mors appear macroscopically as unilocular or multilocular cysts that are often filled with clear fluid. The microscopic appearance is characterized by the presence of uniform cells that form a single layer, covering the cyst walls. Borderline tumors represent $5-10 \%$ of all serous tumors. Their gross appearance is cystic, as their benign counterparts. However, macroscopic papillae are present in the cyst walls. Multi-layering and cellular atypia are seen microscopically, but stromal invasion is absent. Borderline tumors are associated with a favorable outcome, even in the presence of extra-ovarian spread. Ovarian carcinomas often display solid areas macroscopically, and are characterized by the presence of stromal invasion and a desmoplastic stromal reaction.

\subsubsection{Local and distant spread}

Ovarian tumors characteristically spread to other pelvic organs, such as the uterus and the fallopian 
tubes, by means of direct extension. Spread to other pelvic structures can occur by a similar mechanism. Tumors that disrupt the ovarian capsule and grow exophytically are able to shed malignant cells into the peritoneal cavity and cause ascites. Malignant cells in ascites often form extensive and multi-focal tumor implants in the walls of the peritoneal cavity, with a varying extent of intramural invasion. However, the co-existence of lymph node metastases and peritoneal spread in some patients raises the possibility of lymphatic spread as an additional origin of tumor implants $[8,9]$. Serous and undifferentiated carcinomas have been shown to metastasize most often to both pelvic and para-aortic lymph nodes in two studies, and the presence of lymph node metastases correlated with metastatic involvement of other organs [8, 9]. The number of lymph node- positive cases was $32 / 125$ (26\%) for paraaortic lymph nodes and 25/109 (23\%) for pelvic lymph nodes [8,9]. The frequency of other metastases in one of these studies was as follows: positive peritoneal cytology: $61 \%$; pelvic peritoneum: $42 \%$; uterus and tubes: $41 \%$; omentum: $36 \%$; sigmoid colon and rectum: $34 \%$; intestines and mesentery: $28 \%$; subdiaphragmatic surface: $26 \%$; liver and spleen capsule: $10 \%$ [9].

Distant lymphatic and/or hematogenic spread of ovarian carcinomas can involve any organ, including the brain [10], although some organs (e.g., liver) are more frequently involved [11]. Liver involvement was as high as $8 / 47$ (17\%) of patients, second only to pleural effusion, in one series of stage IV carcinomas [12].

\subsubsection{Staging}

Staging of ovarian tumors is based on the federation of gynecological oncologists (FIGO) staging system. This defines stage I tumors as confined to the ovary, stage II tumors as those with pelvic extension, stage III tumors as tumors with intra-peritoneal growth outside the ovaries, and stage IV tumors as those with distant metastatic spread.

\subsubsection{Treatment}

Ovarian carcinomas are treated by surgery combined with chemotherapy, when indicated. Localized disease is treated by hysterectomy and bilateral salpingooophorectomy, with possible conservation of one adnex in young patients in their reproductive years. Disease that has spread beyond the ovary is treated by hysterectomy and bilateral salpingo-oophorectomy with an optimal debulking procedure. The latter attempts the removal of all visible tumor implants. The chemotherapeutic regimen includes platinum-based
Table 1

Possible prognostic factors in ovarian carcinoma

\begin{tabular}{lc}
\hline Prognostic factor & Reference \\
\hline Stage & {$[17]$} \\
Age & {$[17-19]$} \\
Grade & {$[17,20-22]$} \\
Aneuploidy & {$[22-26]$} \\
Histologic type & {$[5]$} \\
Ascites & Discussed in text \\
CA 125 & {$[27,28]$} \\
p53 & {$[29]$} \\
c-erbB-2 and EGF receptor & {$[30-40]$} \\
Colony-stimulating factor-1 (CSF-1) & {$[41,42]$} \\
Urokinase-type plasminogen activator (uPA) & {$[43-46]$} \\
$\quad$ and its inhibitor PAI-1 & \\
Interleukin-6 and -12 (IL-6, IL-12) & {$[47,48]$} \\
Vascular endothelial growth factor (VEGF) & {$[49-58]$} \\
Lrp multidrug resistance marker & {$[59]$} \\
nm23 metastasis-suppressor gene product & {$[60-63]$} \\
p21 oncoprotein & {$[64]$} \\
Glutatione S-transferase & {$[65]$} \\
E-cadherin complex proteins & {$[66-68]$} \\
MUC4 gene & {$[69]$} \\
p27 cyclin-dependent kinase inhibitor & {$[70]$} \\
\hline
\end{tabular}

protocols, often as a combined protocol with cyclophosphamide and doxorubicin [13].

The beneficial role of cytoreductive debulking surgery for ovarian cancer patients was established by Munnell in 1968 and implemented as the standard of therapy for stage III patients based on the studies of Griffiths [14,15] and others [16]. Three recent independent studies established a role for debulking surgery for stage IV patients as well $[11,12,16]$.

\subsubsection{Prognosis}

Established and suggested adverse prognostic factors for ovarian carcinoma patients prior to the initiation of our project are detailed in Table 1 [17-70]. The following merit more detail:

1. Tumor spread beyond the ovary. This is the most important prognostic factor. Stage I tumors are associated with a 5-year survival of $87 \%$, whereas patients diagnosed with stage II, III and IV tumors have a 5-year survival rate of $60 \%, 30 \%$, and $18 \%$, respectively [17].

2. Advanced patient age [17-19]. Patients younger than 40 years have a 5-year survival of $75 \%$, as compared with $21 \%$ for those that are 70 years older or more. 
3. High tumor grade [17,20-22]. Well-differentiated tumors are associated with a 5-year survival of $80 \%$, as compared to $23 \%$ for poorly differentiated ones.

4. Aneuploidy was associated with poor prognosis in some studies [22-25], although the validity of this association was recently challenged [26].

5. Histologic type. Serous and undifferentiated carcinomas have a significantly worse outcome when compared to other morphologic subtypes (endometrioid, mucinous and clear cell carcinomas) [5].

6. The presence of ascites (discussed in detail below).

7. Tumor expression of c-erbB-2 [30-32] and Epidermal growth factor receptor (EGFR) [33,34]. These results have not been confirmed by other studies [35-40].

8. Elevated levels of vascular endothelial growth factor (VEGF) serum levels or protein and mRNA expression in tumor cells [49-54]. These results have not been confirmed in additional studies [55-58].

9. Absence of E-cadherin protein expression [66] and reduced immunoreactivity for $\alpha$-catenin [67] in tumor cells has been associated with poor survival, while nuclear $\beta$-catenin expression predicted favorable outcome [68].

\subsection{Ascites in ovarian carcinoma patients}

Ovarian carcinomas are associated more than any other malignant neoplasm with the accumulation of fluid in the peritoneal cavity. Abdominal discomfort, manifested as abdominal pain, swelling or heaviness, resulting from the presence of ascites is the most common presenting symptom of this disease, occuring in $65 \%$ of patients $[71,72]$. Ascitic accumulation is the combined result of both lymphatic obstruction and increased production of peritoneal fluid by cells lining the peritoneal cavity [73-75]. However, whereas the presence of malignant cells in pleural effusion defines a stage IV disease even in the absence of solid metastases and marks an extremely poor prognosis $[15,16]$, the clinical significance of ascites is controversial. The presence of large-volume ascites correlated with a less favorable prognosis in a subgroup of 390 patients, diagnosed and followed at The Norwegian Radium Hospital, in one study of stage I tumors $(p=0.03$ in Cox regression analysis for survival, $p=0.034$ for relapse) [76]. However, it reached only marginal sig- nificance in another study of 194 patients diagnosed with stage I disease ( $p=0.05)$ [77]. The presence of large-volume ascites correlated with positive peritoneal cytology in an additional study [78]. Two studies of advanced-stage ovarian carcinomas (total number of patients $=585$ ) have shown an association between the presence of ascites and adverse outcome ( $p=0.018, p=0.0001$ ) [79,80]. Conversely, significance $(p=0.035)$ in univariate analysis exclusively [81] or the lack of significance [82] were reported in two additional studies of 267 stage III-IV patients. Three studies of tumors of all stages have associated ascites with poor prognosis $[17,26,83]$ : The presence of tumor-positive ascites was a predictor of death in a study of 59 patients $(p=0.03)$ [26]. Abdominal swelling, as a manifestation of ascites, was associated with a median survival of 1.28 , whereas patients free of the symptom had a median survival of 3.04 years $(p<0.0001)$ [83]. Five-year survival decreased from $29.6 \%$ for stage IV ascites-free patients to $22.1 \%$ and $15.9 \%$ for patients with ascites negative and positive for malignant cells, respectively, in an encompassing study of 21,240 ovarian carcinomas [17]. A study of primary peritoneal carcinomas, tumors that share many of the morphological and clinical characteristics of ovarian carcinomas, failed to demonstrate a similar association [84].

\subsection{The expression of adhesion molecules, carbohydrate antigens and matrix metalloproteinases (MMP) in primary and metastatic ovarian tumors}

Limited and often contradicting data are available regarding the expression of these molecules in primary ovarian carcinomas, when compared to their respective metastatic lesions. Furthermore, no large-scale comparative studies of primary and metastatic lesions compared with effusion specimens have been performed.

Adhesion molecules. Down-regulation of E-cadherin, $\alpha$-catenin and $\beta$-catenin mRNA levels was detected in 17 metastatic lesions when compared to corresponding primary ovarian carcinomas $[85,86]$. However, two studies of E-cadherin expression in a total of 31 ovarian carcinomas using immunohistochemistry and immunoblotting failed to demonstrate a similar difference $[87,88]$.

Although experimental [89-93] and serological [94] studies of integrin, selectin, and CAM molecule expression are available, limited data exist regarding the 
expression of these molecules in a large series of human ovarian carcinomas and/or metastatic lesions. A single study of integrin expression, analyzing 24 ovarian carcinomas, reported an irregular or absent immuonreactivity for $\alpha 6$ and $\beta 4$ integrins in $17 / 24$ and $11 / 24$ tumors in the cell surface or basement membrane region, respectively, when compared with normal ovaries [95]. The expression of $\alpha 2, \alpha 3$ and $\beta 1$ integrins was unaltered [95]. An additional study evaluated the expression of collagen type I in 36 primary borderline or malignant carcinomas of different histologic subtypes and 4 metastatic lesions [96]. Strong irregular peritumoral staining for collagen type I was found in the peritumoral stroma in both poorly differentiated primary tumors and metastatic lesions, as well as in some tumor cells [96].

Carbohydrates. Higher levels $(>41 \mathrm{U} / \mathrm{ml})$ of sialosyl$\mathrm{TN}$ in serum, ascitic fluid and cyst fluid were detected in 48 ovarian carcinomas when compared with benign ovarian tumors, with a decline in serum levels for 14 patients following surgery [97]. Similar epithelial antigen and blood group-related antigen profiles were found in ovarian carcinoma specimens from different sites, including a total of 11 ascites specimens [98,99].

Matrix metalloproteinases. Expression of MMPs and their inhibitors (TIMP) was detected in several studies [100-111]. Comparative studies of primary and metastatic tumors have not been attempted to date.

\subsection{Serous effusions - the diagnostic difficulty}

Malignant neoplasms are characterized by their ability to metastasize to distant organs. Tumor spread frequently involves the serosal surfaces, most often with breast (40\% of malignant effusions) and ovarian (22\% of malignant effusions) carcinomas in female patients [112]. As the finding of malignant cells in serous effusions signifies the spread of disease beyond the organ of origin, it is associated with significant therapeutic and prognostic implications. However, morphological examination of cytological specimens often fails to detect malignant cells in effusions. This is due, in part, to the difficulty in discerning between cancer cells and benign mesothelial cells. Mesothelial cells react to a wide variety of stimuli and injuries that break their continuity by proliferation and reactive cellular changes. Consequently, hyperplastic mesothelial cells in various benign clinical settings undergo marked nuclear and cytoplasmic alterations, some of them mimicking the morphology of malignant cells [112,113]. Furthermore, these changes may follow radiation or chemotherapy, common adjuncts to surgery in the treatment of various malignancies [112]. The diagnostic difficulty is especially noted with ovarian carcinomas, due to the postulated common origin of mesothelial and ovarian surface epithelial cells. In addition, benign conditions (e.g., endosalpingiosis) may be extremely difficult to differentiate from borderline ovarian carcinomas or well-differentiated serous carcinomas in both cytological [114-120] and biopsy specimens [121]. Many studies deal with the differentiation of malignant cells, primarily of epithelial origin, from benign or malignant mesothelial cells in effusions. The reported results can be summarized in the following way:

\subsubsection{Immunohistochemical characterization of epithelial and mesothelial cells in effusions}

Various markers were evaluated for their ability to differentiate between mesothelial and epithelial cells using immunohistochemistry. The primary antibodies applied include carcinoembryonic antigen (CEA), Leu-M1 (CD15), Ber-EP4, MOC-31, B72.3 (anti-TAG 72), and E-cadherin [122-142], all epithelial markers. The sensitivity of CEA immunostaining in these studies ranges from 0 to $100 \%$. However, a comparative evaluation of these reports is impossible. This results from the use of polyclonal vs monoclonal CEA, lack of details regarding the antibody specificity or the tissue origins of the malignant cells that were evaluated, or simply a choice of tumors of various origins. Similarly, the results for Ber-EP4 vary greatly, with a reported sensitivity of $32-100 \%$, and specificity of $12-100 \%$. Nevertheless, nine studies of effusion specimens have demonstrated a specificity of 98-100\%, although with a widely discrepant sensitivity. B72.3 is one of a few antibodies that have demonstrated relatively consistent results in the evaluation of specificity, both in histology specimens and in cytology samples, the range being 96-100\%. The reported sensitivity in these studies varied from $69 \%$ to $100 \%$. Leu-M1 is considered specific for adenocarcinoma cells, but with a relatively low sensitivity (60\%). Markers considered to be mesotheliumlinked are HMBE-1, calretinin, and thrombomodulin [142-144]. The results for these markers vary, with sensitivity of 60-90\% and a specificity range from less than 50-100\%. Epithelial membrane antigen (EMA) is immunoreactive in both malignant mesotheliomas and adenocarcinomas, but the pattern of staining is different, being thick membranous in mesotheliomas and often cytoplasmic in adenocarcinomas. Various other markers, such as lectins (sensitivity $=60-87 \%$, speci- 
ficity $=100 \%$ ), fibronectin (fibronectin-negative/CEA positive combination was seen in $81 \%$ of carcinomas), and desmin (sensitivity $=95 \%$, specificity $=100 \%$ ), were reported as epithelial- or mesothelial-specific in single studies [130,145-147].

Combinations of the above markers led to higher sensitivity and specificity, but no combination resulted in $100 \%$ for both these values.

\subsubsection{DNA ploidy in tumor cells in effusions}

The value of DNA analysis in the diagnosis of malignant cells in effusions (both epithelial and mesothelial) was evaluated in a large number of studies [148154]. It has also been shown in primary ovarian carcinoma [155]. The sensitivity of DNA analysis was compared to immunohistochemical staining with antibodies directed against p53 [148], Ki-67 [149] and various epithelial markers [150]. The importance of standardization of preparation and study protocols, as well as interpretation was highlighted in the ESACP consensus report $[156,157]$. Aneuploid populations were detected in 50-65\% of malignant effusions in most of the abovementioned studies. In one study [158], immunophenotyping of epithelial cells for CEA using flow cytometry was performed, but the small number of effusions that was analyzed $($ no $=6$ ) makes it difficult to interpret the results. The above-detailed reports are in general discouraging, primarily as a result of a relatively low sensitivity, matched against more sensitive and costeffective immunohistochemical studies.

\subsubsection{Cytogenetic studies}

Many cytogenetic studies, using either traditional cytogenetic chromosomal analysis or fluorescent in situ hybridization (FISH), were employed for the diagnosis of both metastatic carcinomas and malignant mesotheliomas in effusions [159-170]. Three of these studies evaluated the presence of double minutes in ovarian [162] or various [164,165] carcinoma cells in effusions. Double minutes were detected in 19/24 ovarian carcinomas and 10/21 and 34/55 carcinomas of different origins. Aneuploidy for chromosome 8 was detected in 75\% (30/40) of breast carcinomas [159] and 20\% (2/10) of pancreatic carcinomas [160] using FISH. Abnormalities in chromosomes 1, 3, 6, 7, 10, and 12 were detected in ovarian carcinomas using cytogenetic chromosomal analysis [170], while other chromosomes (chromosomes 8, 11, 17, 18, $\mathrm{X}$ and $\mathrm{Y}$ ) were additionally abnormal in tumor cells of various origins [161,163,166,168]. Results were less promising for malignant mesotheliomas, due to difficulties in the cytological diagnosis of these tumors [169].

\subsubsection{Proliferation markers}

The expression of proliferation markers in serous effusions was evaluated in a limited number of studies. The number of Ki-67 immunoreactive tumor cells was found to be higher among patients with poor survival, though without statistical significance, in a study of 26 effusions, using the value of $20 \%$ positive counts as cut-off [149]. An additional study of 28 malignant effusions reported a correlation between Ki-67 counts and aneuploidy, with high sensitivity and low specificity in the detection of malignant cells [171]. The average Ki-67 counts for benign, malignant diploid and malignant aneuploid effusions were 11,19 , and 35 , respectively. Proliferating cell nuclear antigen (PCNA) counts were found to be significantly higher in malignant effusions $(p<0.001)$, when compared to benign ones in a study of 87 effusions [172]. Three studies of nucleolar organizer regions (AgNOR) have found this method beneficial in the differentiation of benign mesothelium from malignant cells [173-175]. Differences as high as mean AgNOR counts of 12.57 in nuclei of lung carcinoma cells in effusions, vs. a mean of 3.96 in benign effusions were detected [173]. In contrast, the lack of sensitivity for AgNOR counts was pointed out in a fourth study [176].

\subsection{Serous effusions - studies of genotypic and phenotypic changes involved in the metastatic process}

The above studies have achieved an acceptable level of diagnostic accuracy in serous effusions. The combination of morphology, in the hands of experienced cytopathologists, and an immunohistochemical panel of epithelial and mesothelial markers, leads to a correct diagnosis in over $90 \%$ of cases. The addition of proliferation markers, DNA ploidy, and chromosomal analysis can help in the characterization of exceptionally difficult cases. However, these studies do not offer anything to the understanding of the pathological and biological mechanisms that are responsible for the appearance of metastatic cells in effusions. Although some efforts have been made to analyze the differences between primary tumors from various organs and corresponding distant metastases (see below for ovarian carcinomas), very limited data exists with respect to malignant cells in effusions. The phenotypic and genotypic changes in tumor cells of serous fluids with respect to primary tumors and metastatic lesions and their role in determining patient survival have not been established. Furthermore, comprehen- 
sive studies designed to evaluate the role and presence of molecules that are acknowledged as central in the malignant transformation of cells, as well as in the metastatic process, are lacking. The available studies are often contradictory in their results and conclusions, often due to the inclusion of carcinomas from different origins.

The following data are available to date:

\section{Studies of apoptosis}

The expression of Fas in tumor-associated lymphocytes and monocytes from cancer-associated effusions has been evaluated in one study [177]. However, no studies of apoptosis in tumor cells of serous effusions have been published to date.

\section{Studies of tumor suppressor genes, oncogenes, and} cell cycle proteins

The diagnostic role of p53 immunostaining was evaluated in several studies [148,152,178-183], generally with beneficial results, although a relatively low sensitivity was reported in some of the latter [148]. The role of p53 in the diagnosis of malignant cells in effusions was doubted in one study, due to immunoreactivity in benign mesothelial cells [184]. No molecular studies of p53 gene status in effusions were published to date. p21 and MDM2 immunoreactivity were evaluated in one study [180] using immunohistochemistry. No studies of p15, p16, p21, p27, retinoblastoma gene product, retinoblastoma-related proteins, cyclins, and cdks have been reported.

Few reports of oncogene status in effusions are available. A role for c-myc gene amplification in a small subset of pancreatic carcinomas was postulated in one study [160], but c-myc mRNA was detected in both benign and malignant effusions using northern blotting and in situ hybridization in an additional study [185]. Immunohistochemical staining for c-erbB-2 was found in both benign and malignant conditions in one study, although its inclusion in a panel with anti-p53 and anti-B72.3 resulted in enhanced diagnostic sensitivity [184]. However, c-erbB-2 positivity was detected in adenocarcinomas, primarily of breast and ovarian origin, but not in benign or malignant mesothelial cells in an additional study [186]. Four studies of various carcinomas have demonstrated a diagnostic role for the detection of K-ras and Haras mutations in the characterization of effusions [187190]. K-ras mutations were found in $8 / 9$ pancreatic and $2 / 10$ breast carcinoma cells in effusions $[187,189,190]$. H-ras mutations were detected in $67 \%$ of malignant effusions in a study of 40 benign and malignant effusions [188].

\section{Adhesion molecules}

CD44. Two studies of effusions have postulated a diagnostic role for CD44 variants in the detection of malignant cells in effusions, with contradictory results $[191,192]$. One of the studies above did show a beneficial use of v7 but not of v6 in the detection of malignant cells, using RT-PCR [191]. The second study reported a beneficial role for both $\mathrm{v} 4-5$ and v6 variants, using immunohistochemistry [192]. Filie and coworkers reported no benefit in using CD44 as a marker in cytological specimens [193].

E-cadherin adhesion complex. Three limited studies of E-cadherin expression in effusions, one of gastric carcinomas [194], and two others of unspecified adenocarcinomas [140,141], have reported markedly different results using immunohistochemistry. No studies have evaluated E-cadherin status in effusions using molecular methods. Prior to our report, no studies of catenin status in effusions were published.

Selectins. No studies of selectin status in effusions were published.

Integrins. The expression of $\beta-1, \beta-3$, and $\beta-4$ integrins in resting and activated mesothelial cells, as well as in malignant mesotheliomas, was documented in one study [195]. An additional study reported the presence of the $\beta$-1 integrin subunit in colorectal carcinoma cells in effusions [196].

CAM molecules. The presence of ICAM-1 on mesothelial cells, with concomitant lymphocyte reactivity with anti-LFA-1 was reported in a study of both benign and malignant effusions [197]. ICAM-1 immunoreactivity in metastatic gastric carcinoma cells was reported in an additional study [198]. No studies have evaluated V-CAM status in effusions.

Carbohydrate antigens. Several studies have reported the measurement of carbohydrate tumor-associated antigens in effusions [199]. However, limited data exist on the expression of these molecules on carcinoma cells. CA 19-9 (Sialyl Lewis A) was reported to be highly specific and moderately sensitive for the differentiation of adenocarcinomas from malignant mesotheliomas [143]. The expression of Sialyl Lewis A and Sialyl Lewis X on colorectal carcinoma cells was reported in an additional study [196].

Similar epithelial antigen and blood group-related antigen profiles were found in a study of 12 ovarian carcinomas, analyzing specimens from different sites, including a total of 11 peritoneal effusions [200,201]. 


\section{Proteases}

Cathepsins. A single report has described the presence of a latent form of cathepsin B in pleural effusions in breast cancer patients [202]. No reference to the presence of the enzyme on tumor cells was made. There are no studies on cathepsin D in effusions to date.

Matrix metalloproteinases. The presence of metalloproteinases (MMPs) and their inhibitors (TIMP) in effusions was reported in two studies [203,204], using zymography and western blotting for the study of MMP-2, MMP-8, MMP-9, and TIMP-2. No studies of MMP and TIMP expression in cancer cells in effusions were available prior to our report.

\section{Growth factors}

Transforming growth factor- $\alpha$ (TGF- $\alpha)$ and epidermal growth factor (EGF) levels in effusions were investigated in one study [205]. The former, but not the latter, was detected using radioimmunoassay and radioreceptor assay. No studies were performed regarding EGF or EGF-receptor expression in tumor cells. Platelet-derived growth factor (PDGF) and PDGF receptor were detected on benign mesothelial cells and malignant mesothelioma cells in two studies [206, 207], as well as in the pleural fluid of patients suffering from lung adenocarcinomas [208]. No studies of PDGF expression in metastatic carcinoma cells in effusions are available. Vascular endothelial growth factor (VEGF) levels have been found to be elevated in malignant ascites, when compared with ascites in patients with cirrhosis [209], more so in the presence of metastatic tumor [210]. Fibroblast growth factor (FGF) expression in effusions was not reported to date.

\section{Other markers of malignant cells}

Telomerase. Five studies of telomerase expression in effusions, using PCR [211] and the TRAP assay [212$215]$ were published to date. In the largest study, analyzing 144 pleural effusions, sensitivity of $91.4 \%$ and specificity of $94.2 \%$ have been reported [211].

Multi-drug resistance (MDR). A single report compared the value of three monoclonal antibodies against the MDR-related P-glycoprotein, in a study of both tissue samples and effusions [216].

\subsection{Serous effusions - studies of genotypic and phenotypic changes involved in the metastatic process in ovarian carcinomas}

Many of the above studies have analyzed a small number of tumors. Others have analyzed a larger num- ber of specimens, but included carcinomas of various origins, making the interpretation of results difficult for a given tumor. Still others have failed to specify the origin of the tumors. Only one of the 64 studies detailed in Section 1.4 [114] evaluated ovarian carcinomas exclusively.

The above-detailed data regarding the association of ascites with clinical outcome are indeed inconclusive. Malignant cells in varying numbers are often found in the ascitic fluid, and their presence could be demonstrated in peritoneal washings even in the absence of ascites, a finding that mandates the use of intraoperative washings as part of the clinical staging procedure for gynecological malignancies [217,218]. However, the true nature of these cells in unclear. Whereas malignant cells that originate from ovarian carcinomas are clearly endowed with metastatic properties when present in pleural effusions, the cells in ascites can result from shedding from the tumor surface. These cells have not been defined with respect to their metastatic profile. Neither were they investigated for their possible genotypic and phenotypic alterations when compared with primary tumors, peritoneal metastases and metastases to distant organs.

We have recently initiated a long-term study of the biology of ovarian carcinoma cells in effusions, with the following goals in mind:

1. To improve the diagnostic ability to detect cancer cells in effusions from patients suffering from ovarian carcinomas, using a battery of antibodies designed for the differentiation of epithelial cells from mesothelial and inflammatory cells.

2. To study the genotypic and phenotypic differences between ovarian carcinoma cells in effusions and malignant cells in primary tumors and metastatic lesions in the peritoneal cavity, hollow organs and solid organs. In addition, to compare between malignant cells in ascites and those in pleural effusions, in order to evaluate whether ovarian carcinoma cells in effusions possess true metastatic properties, or are similar to the parent cells in the primary tumor, thereby merely representing the result of shedding of tumor cells. This part included:

A. A study of the expression of matrix metalloproteinases (MMP) and their inhibitors (TIMP) at both protein and mRNA level, using immunohistochemistry, in situ hybridization (ISH) and polymerase chain reaction (PCR) techniques. 
B. A study of carbohydrate antigen expression using immunohistochemistry.

C. A study of E-cadherin complex protein expression using immunohistochemistry, immunoblotting and immunoprecipitation.

3. To analyze the prognostic role of the molecules studied in ovarian carcinoma. This was achieved through a study of solid tumors from a patient cohort consisting of long- and short-term survivors, followed for up to 20 years.

The first study [219] evaluated the role of five epithelial markers in the detection of cancer cells in serous effusions. Eighty-four specimens (61 from patients with a known gynecological neoplasia, 23 consisting of various non-gynecological malignancies or tumors of unknown origin) were studied. Sections were immunocytochemically stained using the antibodies against CA 125, and carcinoembryonic antigen (CEA), as well as the Ber-EP4, BG8 (for Lewis Y blood antigen), and B72.3 (TAG-72) antibodies. Staining in tumor and mesothelial cells was evaluated. When membrane staining was evaluated, all markers except CEA showed sensitivity exceeding 75\%. Membrane positivity using anti-CEA, B72.3 and BerEP4 showed a specificity of $100 \%$. However, membranous staining in mesothelial cells was evident in $13 \%$ and $31 \%$ of cases with the use of BG8 and anti-CA 125 , respectively. The combination of Ber-EP4, B72.3, and BG8 resulted in sensitivity of $95 \%$. Thus, the combination of Ber-EP4 and antibodies directed against and carbohydrate antigens (B72.3 and BG8) proved the most beneficial in the detection of malignant cells in effusions. CEA and CA 125 were shown to have a limited role in the detection of metastases from gynecological tumors due to the low sensitivity of the former and the low specificity of the latter.

After establishing a diagnostic panel for effusions, we began a series of four additional studies of specimens from Norwegian patients diagnosed with ovarian carcinomas. The first study [220] analyzed the diagnostic power of a carbohydrate antigen panel consisting of 5 monoclonal antibodies for Lewis ${ }^{\mathrm{y}}\left(\mathrm{Le}^{\mathrm{y}}\right)(2$ antibodies), Sialyl Lewis ${ }^{\mathrm{x}}$ (Slex), Tn and Sialyl Tn (STn) antigens in 63 malignant and 15 reactive effusions. Up-regulated expression or loss of expression of these molecules on the surface of cancer cells has been previously shown to be associated with a metastatic phenotype and poor survival in epithelial malignancies of different origins. In addition, we compared antigen expression in carcinoma cells in effusions with those of corresponding primary tumors and metastatic lesions $(n=97)$. Staining for the four antigens was seen in carcinoma cells in serous effusions in the majority of cases (range $=71-85 \%$ ). In contrast, immunoreactivity was detected in mesothelial cells in only 6-23\% of the specimens studied. An up-regulation of Tn and STn expression was detected in carcinoma cells in effusions when compared with both primary tumors and metastatic lesions. Expression pattern was similar for tumor cells in pleural and peritoneal effusions. We concluded that cancer-associated carbohydrate antigens are a useful adjunct in the differentiation between malignant epithelial and reactive mesothelial cells. We hypothesized that the up-regulation of Tn and STn may represent a transient phenotypic alteration facilitating metastasis. Finally, the similarities between cells in the pleural and peritoneal cavity provided the first support to our theory, attributing a fully metastatic phenotype to the latter.

In parallel to the study of serous effusions, we began an evaluation of the prognostic role of the molecules designated for the study of cytology specimens. This was achieved through the analysis of two groups of Israeli patients diagnosed with advanced-stage ovarian carcinoma- one with an extremely favorable outcome, the other with a uniformly poor survival. The first study of this cohort [221] investigated the expression of the abovementioned carbohydrate antigens. Sections from 76 primary ovarian carcinomas and metastatic lesions, from 45 patients diagnosed with advanced stage ovarian carcinomas (FIGO stages III-IV), were immunohistochemically stained. Long-term survivors (21 patients) and short-term survivors (24 patients) were defined using a double cut-off of 36 months for diseasefree survival (DFS) and 60 months for overall survival (OS). Staining for all four antigens was seen in the majority of cases (range $=72-96 \%$ ). Absence of immunoreactivity for STn was seen in 9/38 (24\%) metastatic lesions and only $1 / 38(3 \%)$ primary tumors. Primary tumors and metastatic lesions of longterm survivors displayed immunoreactivity patterns that were comparable to those of short-term survivors. However, in survival analysis, more diffuse staining for Slex showed marginal correlation with poor survival, while a trend towards poorer survival was seen in tumors that were more extensively stained for $\mathrm{Le}^{\mathrm{y}}$ and Tn. We concluded that altered expression of STn is observed with tumor progression in a fraction of ovarian carcinomas, and that expression of membrane carbohydrate residues does not appear to be a strong predictor of disease outcome. 
The second study of effusions and solid tumors investigated the expression of E-cadherin complex proteins using immunohistochemistry, immunoblotting, and immunoprecipitation [222]. In addition, we evaluated the dignostic role of calretinin, a mesothelial marker using immunohistochemistry. Sixty-seven malignant effusions and 97 corresponding primary $(=36)$ and metastatic $(=61)$ lesions were immunohistochemically stained for E-cadherin, $\alpha$-, $\beta$ - and $\gamma$-catenin. Membrane immunoreactivity for E-cadherin, $\alpha-, \beta$ and $\gamma$-catenin was often detected on carcinoma cells in effusions, but rarely on reactive mesothelial cells. The opposite distribution was seen for calretinin. An association was seen between E-cadherin and $\alpha$-catenin expression, in both effusions and solid tumors, and for $\beta$-catenin in solid tumors. Up-regulation of all four cadherin complex proteins was seen in carcinoma cells in effusions, when compared to corresponding primary tumors. Similar to effusions, metastatic lesions showed up-regulation of $\alpha-\beta$ - and $\gamma$-catenin when compared to primary carcinomas. Carcinoma cells in effusions showed in addition elevated levels of E-cadherin when compared to metastatic lesions. Staining results were similar for cells in peritoneal and pleural effusions. Immunoblotting (29 malignant effusions) confirmed the presence of all four proteins in the majority of samples, and co-precipitation of E-cadherin and $\beta$-catenin was seen in all 10 examined specimens. E-cadherin complex proteins and calretinin were thus shown to be powerful diagnostic markers in effusions. The similarities in expression in the pleural and peritoneal compartments further attested to the biologic similarities of cancer cells at these sites. The up-regulation of E-cadherin complex proteins in serous effusions and metastatic lesions was hypothesized to mark an early metastatic phenotype, possibly mediating survival of tumor cells at these sites through the inhibition of apoptosis.

The corresponding study of the Israeli cohort [223] analyzed the correlation between expression of E-cadherin complex proteins, epidermal growth factor receptor (EGFR) and c-erbB-2, and disease outcome using immunostochemistry. $\gamma$-catenin protein expression was up-regulated in metastatic lesions. The expression of all studied proteins, with the exception of EGFR, was more diffuse in tumors of short-term survivors. In addition, the presence of cytoplasmic staining for c-erbB-2 was associated with poor survival in survival analysis. Similar results were seen in the evaluation of primary tumors alone for $\gamma$-catenin. The more prevalent expression of E-cadherin complex pro- teins in ovarian carcinomas associated with a rapidly fatal clinical course is in agreement with the findings for the Norwegian patient group, and was hypothesized to be associated with the anti-apoptotic effect attributed to E-cadherin in recent reports.

The third comparative study of the Norwegian patient cohort [224] evaluated protein and mRNA expression of matrix metalloproteinases (MMP) and their inhibitors (TIMP). Sixty-six effusions and 96 tissue sections were stained for MMP-1, MMP-2 and MMP-9 using immunohistochemistry (IHC) and analyzed for mRNA expression of MMP-2, MMP-9 and TIMP-2 using in situ hybridization (ISH). MMP-2 and MMP-9 mRNA levels in 30 effusions were subsequently analyzed using reverse transcription polymerase chain reaction (RT-PCR). MMP and TIMP expression was detected in both carcinoma and mesothelial cells in effusions. However, it was consistently higher in malignant cells, reaching significance for MMP-1 and MMP-2 protein levels, as well as for TIMP-2 mRNA expression. In tissue sections, MMP-1, MMP-2 and MMP-9 protein expression was mostly localized to tumor cells, while mRNA of MMP-2, MMP-9 and TIMP-2 was localized to stromal cells. Adenocarcinoma cells in effusions showed an up-regulation of MMP-2 protein and mRNA expression when compared to primary tumors, with a concomitant down-regulation of TIMP-2 mRNA levels. Cancer cells in peritoneal and pleural effusions again showed comparable expression of all markers. RT-PCR demonstrated the presence of MMP-2, but not MMP-9, in 28/30 specimens.

We concluded that malignant epithelial cells have a central role in the synthesis of metalloproteinases and their inhibitors in serous effusions, while stromal cells have the corresponding role in solid tumors, both primary and metastatic. MMP-1 and MMP-2 production predominates, while that of MMP-9 is negligible. Upregulation of MMP-2 and down-regulation of TIMP-2 mRNA levels occurs in ovarian carcinoma cells in effusions, possibly marking the acquisition of a metastatic phenotype. Carcinoma cells in peritoneal and pleural effusions possess a similar MMP profile, further establishing the true metastatic nature of the former.

In the next study, aimed at further investigating MMP status in effsusions, we analyzed mRNA expression of membrane-type metalloproteinases (MTMMPs), and its correlation with the expression of matrix metalloproteinase-2 (MMP-2) [225]. The levels of MMP-2, MT1-MMP, MT2-MMP and MT3-MMP were evaluated in 43 malignant pleural and peritoneal effusions using reverse transcription-polymerase chain 
reaction (RT-PCR). The cellular localization of MT1MMP was additionally studied in 66 effusion specimens and 85 primary and metastatic tumors (total $=$ 151) using mRNA in situ hybridization (ISH). MMP-2 mRNA was detected in 37/43, MT1-MMP in 25/43, and MT2-MMP in 32/43 effusions, using RT-PCR. MT2-MMP mRNA expression was detected more often in effusions consisting predominantly of carcinoma cells $(91 \%)$ than in those with a mixed cellular population (60\%), while MMP-2 and MT1-MMP were equally detected in both effusion types. MT3-MMP mRNA was not detected in any of the studied effusions. High levels of MMP-2 mRNA were more often detected in effusions with high MT1- and/or MT2-MMP mRNA expression. Using ISH, MT1-MMP mRNA was localized predominantly to cancer cells in both malignant effusions and solid lesions. Tumor cell MT1-MMP expression in effusion specimens did not differ from neither primary nor metastatic lesions. As for the molecules in previous studies, MT-MMP expression in tumor cells in effusions showed no association with effusion site using both ISH and PCR. We concluded that MT1- and MT2-MMP mRNA are both expressed in serous effusions of ovarian carcinoma patients, in some cases in a mutually exclusive manner. mRNA of both enzymes is localized primarily to tumor cells and is often co-expressed with MMP-2 mRNA. MT3-MMP mRNA does not appear to be expressed by ovarian carcinomas.

The final study of the Israeli cohort analyzed the potential association between the expression of MMP-2, MMP-9, MT1-MMP and TIMP-2, and disease outcome [226]. Sections from 36 primary ovarian carcinomas and 34 metastatic lesions (total $=70$ ) were studied using mRNA in situ hybridization (ISH) technique. Intense mRNA signals were detected more frequently in tumor cells of short-term survivors with use of all four probes. Comparable findings were observed in peritumoral stromal cells with ISH for MMP-2, MMP-9 and TIMP-2 mRNA. Primary tumors with intense mRNA signal for TIMP-2 (no = 14) were uniformly associated with a fatal outcome. In univariate analysis of primary tumors, mRNA levels of TIMP-2 in stromal cells, as well as for MMP-9 and TIMP-2 in tumor cells, correlated with poor outcome. In univariate analysis of metastatic lesions, mRNA levels of TIMP-2 in stromal cells, as well as for MMP-2 and MT1-MMP in tumor cells, correlated with poor outcome. The presence of MT1-MMP in stromal cells correlated with longer survival. In a multivariate analysis of ISH results for primary tumors, TIMP-2 levels in stromal cells and MMP-9 levels in tumor cells retained their predictive value. We concluded that MMP-2, MMP-9, MT1-MMP and TIMP-2 are valid markers of poor survival in advanced-stage ovarian carcinoma.

\section{Perspectives}

In the first phase of our study of ovarian carcinoma cells in effusions, we analyzed the expression of several molecules associated with epithelial differentiation, malignant transformation, cellular adhesion, invasion and metastasis. The object was to interpret the assembled data in the light of three central questions related to ovarian carcinogenesis. These will be discussed separately here.

\subsection{The diagnostic problem}

An experienced cytopathologist can diagnose correctly the majority of body cavity effusions met in everyday practice. There is, however, little doubt that mistaken diagnoses occur far too often with the use of morphology alone. Caution is advised in the interpretation of effusion morphology due to the ability of mesothelial cells to masquerade as malignant cells, as a result of architectural and cellular alterations associated with their reaction to numerous stimuli. However, in view of the overwhelming majority of falsenegative diagnoses in many laboratories, the ability of malignant cells to masquerade as benign cells and avoid recognition in routine smears is of no lesser concern. To further confound matters, macrophages are able to present themselves as indistinguishable from both mesothelial and tumor cells. The use of ancillary methods in effusion diagnosis is therefore mandated in all but unequivocal cases. Electron microscopy has in the past been regarded as the gold standard for this purpose [120]. However, it is not available in many institutions and demands specialized personnel. Immunohistochemistry has consequently become the method of choice in most hospitals. Numerous reports are available regarding the value of these markers [123-147], but still it is difficult to draw practical conclusions. This reflects the inclusion of tumors of different origins, different antibodies, and different staining protocols. In addition, the protocol used for the morphologic diagnosis, which provides the basis for the immunocytochemical interpretation, is often not detailed. Our first study included several tumor types, but focused on ovarian carcinomas. It reproduced the beneficial results 
associated with the use of antibodies directed against carbohydrate antigens in the diagnosis of metastatic adenocarcinomas. It also pointed to the usefulness of Ber-EP4 in this scenario. Most of all, it helped us to establish an efficient protocol, involving both a double blind morphologic diagnosis (followed by discussion of problematic specimens) and a battery of markers for the detection of cancer cells. In this panel we were subsequently able to include additional carbohydrate antigens, as well as E-cadherin and the three cadherins, the latter previously not investigated for this role. This use of this protocol resulted in a diagnostic accuracy approaching $100 \%$.

\subsection{Prognostic data}

The prognosis for ovarian carcinoma patients remains poor. Despite the inclusion of new effective chemotherapeutic agents, such as Paclitaxel, in current treatment protocols, long-term survival in advancedstage ovarian carcinoma is an unusual event. Still, as most patients present with stage III/IV disease, effort should be directed towards the definition of prognostic markers among this group. We have recently characterized a patient cohort of long-term survivors diagnosed with advanced-stage ovarian carcinoma, with an average overall survival of 10 years. We compared marker expression in tumors of these patients with those obtained from patients with poor outcome, matched for age, tumor type, histological grade, and stage. Differences in expression were seen for the majority of studied molecules, reflecting their central role in the malignant phenotype and tumor progression. We were able to confirm the prognostic role of MMP-2, previously shown to be a marker of adverse outcome on protein level, studying mRNA expression. We also provided first evidence of correlation between mRNA expression of two additional MMPs, MMP-9 and MT1MMP, and poor survival in ovarian carcinoma. Finally, stromal expression of TIMP-2, previously thought to be an inhibitor of MMPs and thus a marker of favorable outcome, was shown to be the strongest predictor of poor outcome. The latter finding is in agreement with reports for other carcinomas, as well as with the recently described role of TIMP-2 in the activation of MMP-2, together with MT1-MMP [227-229]. Studying the expression of E-cadherin complex proteins, we subsequently demonstrated higher expression of E-cadherin, as well as $\alpha$-, $\beta$-, and $\gamma$-catenin in tumors of short-term survivors, statistically significant for the latter marker. These findings are in agreement with recent studies of other epithelial malignancies, reporting up-regulation of these molecules in metastatic lesions, as well as anti-apoptotic effect of E-cadherin expression in vitro. Thus, the simplified view, associating loss of E-cadherin complex protein expression with tumor progression and poor survival, appears to apply to some, but not all, epithelial malignancies. The low incidence of mutations in the genes coding for these proteins in ovarian carcinomas [230], and the reported beneficial prognostic role of $\beta$-catenin mutations in early-stage ovarian carcinoma [231] support, together with our findings for both patient cohorts [222,223], the opposite role for these molecules in ovarian carcinogenesis. Finally, expression of three of the four carbohydrate antigens studied was higher in tumors of short-term survivors. Although of marginal or no statistical significance, this finding may represent up-regulated expression of tumor-associated glycoproteins, known to contain these molecules, in aggressive tumors.

Put together, these data point to the potential biological and prognostic significance of studying advancedstage ovarian carcinomas with differing outcomes. We have recently reported on the prognostic role of the transcription factor Ets-1 [232] and the $\alpha \mathrm{v}$ integrin chain [233] in this cohort. Although patients with localized disease constitute the vast majority of potentially curable cases, characterization of the molecular genotypic and phenotypic traits of tumors from longterm survivors may provide useful information for future therapeutic interventions.

\subsection{The metastatic sequence in ovarian carcinoma}

There is little doubt that the main pathway involved in dissemination of ovarian carcinomas utilizes the peritoneal cavity and the organs within it. Distant metastases often occur late and are clearly less prevalent than their intra-abdominal counterparts. The widely accepted mechanism for this phenomenon is a process of direct shedding from the surface of the ovary, accompanied by the accumulation of ascitic fluid. Taken as such, one would tentatively expect these cells to show little, if any difference from the cells in the primary tumor from which they originated. Following the same line of thought, cells in peritoneal effusions would have to differ from those in pleural effusions, as the latter are accepted as fully metastatic and define stage IV disease. However, most of the studies that compared primary tumors and effusions included far too few (mostly ten or less) cases for any 
conclusions to be drawn [201]. Comparative studies of carcinoma cells in the pleural and peritoneal cavities are not available even on a limited scope. Our results in the four studies presented show that ovarian carcinoma cells in primary tumors and effusions are all but similar. This finding is substatiated by the results of several additional studies of metastasis-associated and regulatory molecules, such as the adhesion molecule CD44s [234], angiogenic genes [235], nerve growth factor receptors [236] and integrins (Davidson et al., submitted) performed by our group.

The differences between cancer cells in primary tumors and effusions can be the result of several factors:

1. Differences in microenvironment. The central interaction of cancer cells in solid tissues is with peritumoral stromal cells of fibroblastic origin. Endothelial cells and a usually sparse inflammatory infiltrate are additional candidates. Although the latter cell population is present (to an extremely variable extent) in effusions, stromal and endothelial cells are substituted by mesothelial cells. These are indeed of mesenchymal origin, but differ morphologically and phenotypically, as well as with respect to synthesized molecules, from stromal cells of solid tissues. Mesothelial cells are indeed capable of elaborating several molecules involved in adhesion, invasion and cellular signaling (e.g., integrins, CD44 and CAM molecules). However, their cellular representation in effusions ranges from practically nil to florid reactions in which an isolated cancer cell is "drowned" in a sea of reactive cells. Still, secretion of various mediators by mesothelial cells lining the peritoneal cavity may induce some of the alterations observed in cancer cells. Regrettably, this theory fails to explain the similarities between ovarian cells in effusions and those in solid metastases observed in this study.

2. Treatment-induced differences. A considerable fraction $(70-80 \%)$ of the studied effusions has been obtained from patients suffering a relapse after one or more courses of chemotherapy. In contrast, many of the solid tumors studied were obtained at primary operation, before adjuvant therapy was instituted. Chemotherapeutic agents induce a large number of cellular alterations, some of which could have affected the expression of the molecules studied. However, this theory fails to provide an explanation for the differences between primary and metastatic lesions removed from the patient on the same day, and for the similarities between pre-treatment metastases and postor mid-treatment effusions. Thus, although the role of chemotherapy in modifying genes and proteins in can- cer cells merits attention, it does not provide a satisfactory explanation for this biological dilemma.

3. Technical factors. Having instituted the prospective collection of effusion specimens, we also established a working protocol, designed to enable rapid and efficient treatment of all sumbitted specimens. Care was exercised to minimize the time between their arrival to the department and their evaluation. Even if we assume that all specimens were treated in the same manner, the possibility exists that the corresponding surgical specimens were subjected to different conditions (e.g., different fixation time in formalin), that are able to influence protein and mRNA expression. As pointed above, we would expect to find differences between effusions and solid lesions, and not between primary tumors and metastases/effusions. The use of appropriate controls (e.g., GAPDH in RT-PCR, poly d(T) in ISH) aided in ruling out the possibility of non-viable tissue.

In conclusion, our studies so far have attempted to define some of the alterations undergone by ovarian carcinoma cells in effusions, and to evaluate these findings in view of the current knowledge regarding the metastatic sequence in ovarian carcinoma. It would be presumptive to assume that the identity of ovarian carcinoma cells in the peritoneal cavity can be elucidated as a result of these preliminary studies. It would be similarly naive, however, to accept without questioning the shedding hypothesis as the exclusive interpretation of tumor progression in ovarian carcinogenesis. The differences between the cells in ascites and those of the corresponding primary tumors show that these cells undergo a series of alterations after leaving their native organ. Some of these (as catenin expression) remain in solid metastases, while others are modified or dampened (E-cadherin or MMP-2 expression). Our recent studies suggest that expression in solid metastases is often intermediate between primary tumors and effusions, raising the possibility of an entirely different sequence of disease progression (from primary tumor to solid metastasis to effusion) rather than the accepted one. Whatever the underlying mechanism, the differences between carcinoma cells in primary tumors and effusions may have far-reaching therapeutic consequences, as we are probably dealing with two biologically distinct cell populations. The striking similarities between cells in pleural effusions (universally accepted as fully metastatic) and peritoneal effusions lend additional support to our hypothesis that the latter are of fully metastatic nature. Futhermore, they point to the lack of any biological basis for the clinical distinction between carcinoma cells at these two sites. 


\section{References}

[1] D.M. Parkin, P. Pisani and J. Ferlay, Global cancer statistics, CA Cancer J. Clin. 49 (1999), 33-64.

[2] OPCS mortality statistics DH2; Cause, England and Wales 1986, Her Majesty's Stationary Office, London, United Kingdom, 1993.

[3] T. Bjorge, A. Engeland, S. Hansen and C.G. Tropé, Prognosis of patients with ovarian cancer and borderline tumours diagnosed in Norway between 1954 and 1993, Int. J. Cancer 75 (1998), 663-670.

[4] F. Petterson, International Federation of Gynecology and Obstetrics: Annual report on the results of treatment in gynecological cancer, Panorama Press AB, Stockholm, Sweden, 1995, pp. 83-102, 201-227.

[5] C. Zaloudek, Ovarian neoplasms, in: Pathology in Gynecology and Obstetrics, C. Gompel and S.G. Silverberg, eds, Lippincott, Philadelphia, 1994, pp. 330-402.

[6] J. Rosai, Therapy and prognosis of ovarian carcinoma, in: Ackerman's Surgical Pathology, J. Rosai, ed., Vol. 1, Mosby, St. Louis, 1996, pp. 1492-1493.

[7] R.H. Young, P.B. Clement and R.E. Scully, Surface epithelialstromal tumors, in: Diagnostic Surgical Pathology, 3rd edn, S.S. Sternberg, D.A. Antonioli, D. Carter, S.E. Mills and H.A. Oberman, eds, Lippincott Williams \& Wilkins, Philadelphia, 1999, pp. 2319-2382.

[8] K. Sakai, T. Kamura, T. Hirakawa, T. Saito, T. Kaku and H. Nakano, Relationship between pelvic lymph node involvement and other disease sites in patients with ovarian cancer, Gynecol. Oncol. 65 (1997), 164-168.

[9] N. Tsuruchi, T. Kamura, N. Tsukamoto, K. Akazawa, T. Saito, T. Kaku, N. To and H. Nakano, Relationship between paraaortic lymph node involvement and intraperitoneal spread in patients with ovarian cancer - a multivariate analysis, Gynecol. Oncol. 49 (1993), 51-55.

[10] G. Cormio, A. Maneo, G. Parma, M.R. Pittelli, M.D. Miceli and $\mathrm{C}$. Bonazzi, Central nervous system metastases in patients with ovarian carcinoma. A report of 23 cases and literature review, Ann. Oncol. 6 (1995), 571-574.

[11] A.R. Munkarah, A.V. Hallum 3rd, M. Morris, T.W. Burke, C. Levenback, E.N. Atkinson, J.T. Wharton and G.M. Gershenson, Prognostic significance of residual disease in patients with stage IV epithelial ovarian cancer, Gynecol. Oncol. 64 (1997), 13-17.

[12] P.C. Liu, I. Benjamin, M.A. Morgan, S.A. King, J.J. Mikuta and S.C. Rubin, Effect of surgical debulking on survival in stage IV ovarian cancer, Gynecol. Oncol. 64 (1997), 4-8.

[13] C. Tropé and G. Kristensen, Current status of chemotherapy in gynecologic cancer, Semin. Oncol. 24 (1997) S15-1-S1522.

[14] C.T. Griffiths, Surgical resection of tumor bulk in the primary treatment of ovarian carcinoma, Natl. Cancer Inst. Monogr. 42 (1975), 101-104

[15] C.T. Griffiths, L.M. Parker and A.J. Fuller, Role of cytoreductive surgical treatment in the management of advanced ovarian cancer, Cancer Treat. Rep. 63 (1979), 235-240.

[16] J.P. Curtin, R. Malik, E.S. Venkatraman, R.R. Barakat and W.J. Hoskins, Stage IV ovarian cancer: impact of surgical debulking, Gynecol. Oncol. 64 (1997), 9-12.
[17] C.L. Kosary, FIGO stage, histology, histologic grade, age and race as prognostic factors in determining survival for cancers of the female gynecological system: an analysis of 1973-1987 SEER cases of cancers of the endometrium, cervix, ovary, vulva and vagina, Semin. Surg. Oncol. 10 (1994), 31-46.

[18] U. Beller, B. Bigelow, E.M. Beckman, B. Brown and R.I. Demopoulos, Epithelial carcinoma of the ovary in the reproductive years. Clinical and morphological characterization, $G y$ necol. Oncol. 15 (1983), 422-427.

[19] T. Thigpen, M.F. Brady, G.A. Omura, W.T. Creasman, W.P. McGuire, W.J. Hoskins and S. Williams, Age as a prognostic factor in ovarian carcinoma. The Gynecologic Oncology Group experience, Cancer 71 (1993), 606-614.

[20] G.D. Malkasian, L.J. Melton, P.C. O'Brien and M.H. Greene, Prognostic significance of histologic classification and grading of epithelial malignancies of the ovary, Am. J. Obstet. Gynecol. 149 (1984), 274-284.

[21] B. Sorbe, B.O. Frankendal and B.Veress, Importance of histologic grading in the prognosis of epithelial ovarian carcinoma, Obstet. Gynecol. 59 (1982), 576-582.

[22] I.B. Vergote, J. Kaern, V.M. Abeler, E.O. Pettersen, L.N. DeVos and C.G. Tropé, Analysis of prognostic factors in stage I epithelial ovarian carcinoma: importance of degree of differentiation and deoxyribonucleic acid ploidy in predicting relapse, Am. J. Obstet. Gynecol. 169 (1993), 40-52.

[23] J. Kaern, C.G. Tropé, G.B. Kristensen, K.M. Tveit and E.O. Pettersen, Evaluation of deoxyribonucleic acid ploidy and S-phase fraction as prognostic parameters in advanced epithelial ovarian carcinoma: a prospective study, Am. J. Obstet. Gynecol. 170 (1994), 479-487.

[24] K. Erhardt, G. Auer, E. Bjorkholm, G. Forsslund, B. Moberger, C. Silfversward, G. Wicksell and A. Zetterberg, Combined morphologic and cytochemical grading of serous ovarian tumors, Am. J. Obstet. Gynecol. 151 (1985), 356-361.

[25] G.E. Feichter, W. Kuhn, B. Czernobilsky, A. Muller, J. Heep, U. Abel, D. Haag, M. Kaufmann, H.H. Rummel, F. Kubli and K. Goerttler, DNA flow cytometry of ovarian tumors with correlation to histopathology, Int. J. Gynecol. Pathol. 4 (1985), 336-345.

[26] L.W. Rice, S.D. Mark, R.S. Berkowitz, B.A. Goff and J.M. Lage, Clinicopathologic variables, operative characteristics and DNA ploidy in predicting outcome in ovarian epithelial carcinoma, Obstet. Gynecol. 86 (1995), 379-385.

[27] A.P. Makar, G.B. Kristensen, J. Kaern, O.P. Bormer, V.M. Abeler and C.G. Tropé, Prognostic value of pre- and postoperative serum CA 125 levels in ovarian cancer: new aspects and multivariate analysis, Obstet. Gynecol. 79 (1992), 1002-1010.

[28] A.P. Makar, G.B. Kristensen, O.P. Bormer and C.G. Tropé, CA 125 measured before second-look laparotomy is an independent prognostic factor for survival in patients with epithelial ovarian cancer, Gynecol. Oncol. 45 (1992), 323-328.

[29] M.A. Levesque, D. Katsaros, H. Yu, P. Zola, P. Sismondi, G. Giardina and E.P. Diamandis, Mutant p53 protein overexpression is associated with poor outcome in patients with well or moderately differentiated ovarian carcinoma, Cancer 75 (1995), 1327-1338. 
[30] H. Meden, D. Marx, T. Rath, M. Kron, A. Fattahi-Meibodi, B. Hinney, W. Kuhn and A. Schauer, Overexpression of the oncogene c-erbB2 in primary ovarian cancer. Evaluation of the prognostic value in a Cox proportional hazards multiple regression, Int. J. Gynecol. Pathol. 13 (1994), 45-53.

[31] E. Felip, J.M. Del Campo, D. Rubio, M.T. Vidal, R. Colomer and B. Bermejo, Overexpression of c-erbB-2 in epithelial ovarian cancer. Prognostic value and relationship with response to chemotherapy, Cancer 75 (1995), 2147-2152.

[32] A. Berchuck, A. Kamel, R. Whitaker, B. Kerns, G. Olt, R. Kinney, J.T. Soper, R. Dodge, D.L. Clarke-Pearson, P. Marks, S. McKenzie, S. Yin and R.C. Bast, Jr., Overexpression of $H E R-2 / n e u$ is associated with poor survival in advanced epithelial ovarian cancer, Cancer Res. 50 (1990), 4087-4091.

[33] A. Berchuck, G.C. Rodriguez, A. Kamel, R.K. Dodge, J.T. Soper, D.L. Clarke-Pearson and R.C. Bast, Jr., Epidermal growth factor receptor expression in normal ovarian epithelium and ovarian cancer, I. Correlation of receptor expression with prognostic factors in patients with ovarian cancer, Am. J. Obstet. Gynecol. 164 (1991), 669-674.

[34] G. Scambia, P.B. Panici, F. Battaglia, G. Ferrandina, G. Baiocchi, S. Greggi, R. De Vincenzo and S. Mancuso, Significance of epidermal growth factor receptor in advanced ovarian cancer, J. Clin. Oncol. 10 (1992), 529-535.

[35] M.E.L. van der Burg, S.C. Henzen-Logmans, J.A. Foekens, E.M.J.J. Berns, C.J. Rodenburg, W.L.J. van Putten and J.G.M. Klijn, The prognostic value of epidermal growth factor receptors, determined by both immunohistochemistry and ligand binding assays, in primary epithelial ovarian cancer: a pilot study, Eur. J. Cancer 29 (1993), 1951-1957.

[36] M. Baekelandt, G.B. Kristensen, C.G. Tropé, J.M. Nesland and R. Holm, Epidermal growth factor expression has no independent prognostic significance in advanced ovarian cancer, Anticancer Res. 19 (1999), 4469-4474.

[37] B.A. Goff, J.A. Ries, L.P. Els, M.D. Coltrera and A.L. Gown, Immunophenotype of ovarian cancer as predictor of clinical outcome: evaluation at primary surgery and second-look procedure, Gynecol. Oncol. 70 (1998), 378-385.

[38] T.P. Singleton, T. Perrone, G. Oakley, G.A. Niehans, L. Carson, S.S. Cha and J.G. Strickler, Activation of c-erbB-2 and prognosis in ovarian carcinoma. Comparison with histologic type, grade and stage, Cancer 73 (1994), 1460-1466.

[39] A. Fajac, J. Benard, C. Lhomme, A. Rey, P. Duvillard, F. Rochard, J.F. Bernaudin and G. Riou, c-erbB2 gene amplification and protein expression in ovarian epithelial tumors: evaluation of their respective prognostic significance by multivariate analysis, Int. J. Cancer 64 (1995), 146-151.

[40] M. Medl, P. Sevelda, K. Czerwenka, K. Dobianer, H. Hanak, C. Hruza, M. Klein, S. Leodolter, S. Mullauer-Ertl, A. Rosen, H. Salzer, N. Vavra and J. Spona, DNA amplification of HER2/neu and INT-2 oncogenes in epithelial ovarian cancer, $G y$ necol. Oncol. 59 (1995), 321-326.

[41] F.V. Price, S.K. Chambers, J.T. Chambers, M.L. Carcangiu, P.E. Schwartz, E.I. Kohorn, E.R. Stanley and B.M. Kacinski, Colony-stimulating factor- 1 in primary ascites of ovarian cancer is a significant predictor of survival, Am. J. Obstet. Gynecol. 168 (1993), 520-527.
[42] S.K. Chambers, B.M. Kacinski, C.M. Ivins and M.L. Carcangiu, Overexpression of epithelial macrophage colonystimulating factor (CSF-1) and CSF-1 receptor: A poor prognostic factor in epithelial ovarian cancer, contrasted with a protective effect of stromal CSF-1, Clin. Cancer Res. 3 (1997) 999-1007.

[43] W. Kuhn, L. Pache, B. Schmalfeldt, P. Dettmar, M. Schmitt, F. Janicke and H. Graeff, Urokinase (uPA) and PAI-1 predict survival in advanced ovarian cancer patients (FIGO III) after radical surgery and platinum-based chemotherapy, Gynecol. Oncol. 55 (1994), 401-409.

[44] C.F. Sier, R. Stephens, J. Bizik, A. Mariani, M. Bassan, N. Pedersen, L. Frigerio, A. Ferrari, K. Dano, N. Brunner and F. Blasi, The level of urokinase-type plasminogen activator receptor is increased in serum of ovarian cancer patients, Cancer Res. 58 (1998), 1843-1849.

[45] S.K. Chambers, R.E. Gertz, Jr., C.M. Ivins and B.M. Kacinski, The significance of urokinase-type plasminogen activator, its inhibitor and its receptor in ascites of patients with epithelial ovarian cancer, Cancer 75 (1995), 1627-1633.

[46] S.K. Chambers, C.M. Ivins and M.L. Carcangiu, Expression of plasminogen activator inhibitor-2 in epithelial ovarian cancer: a favorable prognostic factor related to the actions of CSF-1, Int. J. Cancer 74 (1997), 571-575.

[47] G. Scambia, U. Testa, P. Benedetti Panici, E. Foti, R. Martucci, A. Gadducci, A. Perillo, V. Facchini, C. Peschle and S. Mancuso, Prognostic significance of interleukin 6 serum levels in patients with ovarian cancer, Br. J. Cancer 71 (1995), 354-356.

[48] A.G. Zeimet, M. Widschwendter, C. Knabbe, D. Fuchs, M. Herold, E. Muller-Holzner, G. Daxenbichler, F.A. Offner, O. Dapunt and C. Marth, Ascitic interleukin-12 is an independent prognostic factor in ovarian cancer, J. Clin. Oncol. 16 (1998), 1861-1868.

[49] D. Hazelton, R.F. Nicosia and S.V. Nicosia, Vascular endothelial growth factor levels in ovarian cyst fluid correlate with malignancy, Clin. Cancer Res. 5 (1999), 823-829.

[50] C.A. Chen, W.F. Cheng, C.N. Lee, T.M. Chen, C.C.S. Kung, F.J. Hsieh and C.Y. Hsieh, Serum vascular endothelial growth factor in epithelial ovarian neoplasms: correlation with patient survival, Gynecol. Oncol. 74 (1999), 235-240.

[51] C. Tempfer, A. Obermair, L. Hefler, G. Haeusler, G. Gitsch and C. Kainz, Vascular endothelial growth factor serum concentrations in ovarian cancer, Obstet. Gynecol. 92 (1998), 360-363.

[52] G.G. Garzetti, A. Ciavattini, G. Lucarini, A. Pugnaloni, M. De Nictolis, S. Amati, C. Romanini and G. Biagini, Vascular endothelial growth factor expression as a prognostic index in serous ovarian cystadenocarcinomas: relationship with MIB1 immunostaining, Gynecol. Oncol. 73 (1999), 396-401.

[53] S. Yamamoto, I. Konishi, M. Mandai, H. Kuroda, T. Komatsu, K. Nanbu, T. Sakahara and T. Mori, Expression of vascular endothelial growth factor (VEGF) in epithelial ovarian neoplasms: correlation with clinicopathology and patient survival and analysis of serum VEGF levels, Br. J. Cancer 76 (1997), 1221-1227.

[54] P.J. Paley, K.A. Staskus, K. Gebhard, D. Mohanraj, L.B. Twiggs, L.F. Carson and S. Ramakrishnan, Vascular endothelial growth factor expression in early-stage ovarian carcinomas, Cancer 80 (1997), 98-106. 
[55] A. Gadducci, M. Ferdeghini, A. Fanucchi, C. Annicchiarico, B. Ciampi, C. Prontera and A.R. Genazzani, Serum preoperative vascular endothelial growth factor (VEGF) in epithelial ovarian cancer: relationship with prognostic variables and clinical outcome, Anticancer Res. 19 (1999), 1401-1406.

[56] Y. Nakanishi, J. Kodama, M. Yoshinouchi, K. Tokumo, S. Kamimura, H. Okuda and T. Kudo, The expression of vascular endothelial growth factor and transforming growth factor $-\beta$ associates with angiogenesis in epithelial ovarian cancer, Int. J. Gynecol. Pathol. 16 (1997), 256-262.

[57] E.M. Hartenbach, T.A. Olson, J.J. Goswitz, D. Mohanraj, L.B. Twiggs, L.F. Carson and S. Ramakrishnan, Vascular endothelial growth factor (VEGF) expression and survival in human epithelial ovarian carcinomas, Cancer Lett. 121 (1997), 169-175.

[58] J. Mattern, G. Stammler, R. Koomagi, D. Wallwiener, M. Kauffman and M. Volm, Association of vascular endothelial growth factor expression with tumor cell proliferation in ovarian carcinoma, Anticancer Res. 17 (1997), 621-624.

[59] M.A. Izquierdo, A.G. van der Zee, J.B. Vermorken, P. van der Valk, J.A. Belien, G. Giaccone, G.L. Scheffer, M.J. Flens, H.M. Pinedo, P. Kenemans, C.J.L.M. Meijer, E.G.E. de Vries and R.J. Scheper, Drug resistance-associated marker Lrp for prediction of response to chemotherapy and prognoses in advanced ovarian carcinoma, J. Natl. Cancer Inst. 87 (1995), 1230-1237.

[60] G. Scambia, G. Ferrandina, M. Marone, P. Benedetti Panici, C. Giannitelli, M. Piantelli, A. Leone and S. Mancuso, nm23 in ovarian cancer: correlation with clinical outcome and other clinicopathologic and biochemical prognostic parameters, J. Clin. Oncol. 14 (1996), 334-342.

[61] M. Mandai, I. Konishi, T. Komatsu, T. Mori, S. Arao, H. Nomura, Y. Kanda, H. Hiai and M. Fukumoto, Mutation of the $\mathrm{nm} 23$ gene, loss of heterozygosity at the $\mathrm{nm} 23$ locus and K-ras mutation in ovarian carcinoma: correlation with tumour progression and nm23 gene expression, Br. J. Cancer $\mathbf{7 2}$ (1995), 691-695

[62] A. Viel, L. Dall'Agnese, V. Canzonieri, F. Sopracordevole, E. Capozzi, A. Carbone, M.C. Visentin and M. Boiocchi, Suppressive role of the metastasis-related $\mathrm{nm} 23-\mathrm{H} 1$ gene in human ovarian carcinomas: association with high messenger RNA expression with lack of lymph node metastasis, Cancer Res. 55 (1995), 2645-2650.

[63] M. Mandai, I. Konishi, M. Koshiyama, T. Mori, S. Arao, S. Tashiro, H. Okamura, H. Nomura, H. Hiai and M. Fukumoto, Expression of metastasis-related $\mathrm{nm} 23-\mathrm{H} 1$ and $\mathrm{nm} 23-$ $\mathrm{H} 2$ genes in ovarian carcinomas: correlation with clinicopathology, EGFR, c-erbB-2 and c-erb-B3 genes, and sex steroid receptor expression, Cancer Res. 54 (1994), 18251830.

[64] G. Scambia, V. Masciullo, P. Benedetti Panici, M. Marone, G. Ferrandina, N. Todaro, A. Bellacosa, S.K. Jain, G. Neri, A. Piffanelli and S. Mancuso, Prognostic significance of ras $/ \mathrm{p} 21$ alterations in human ovarian cancer, Br. J. Cancer $\mathbf{7 5}$ (1997), 1547-1553.

[65] G. Ferrandina, G. Scambia, G. Damia, G. Tagliabue, A. Fagotti, P. Benedetti Panici, C. Mangioni, S. Mancuso and M. D'Incalci, Glutathione S-transferase activity in epithelial ovarian cancer: association with response to chemotherapy and disease outcome, Ann. Oncol. 8 (1997), 343-350.
[66] E. Darai, J.Y. Scoazec, F. Walker-Combrouze, N. MlikaCabanne, G. Feldmann and P. Madelenat, Expression of cadherins in benign, borderline and malignant ovarian epithelial tumors: a clinicopathologic study of 60 cases, Hum. Pathol. 28 (1997), 922-928.

[67] M. Anttila, V.M. Kosma, H. Ji, X. Wei-Ling, J. Puolakka, M. Juhola, S. Saarikoski and K. Syrjänen, Clinical significance of $\alpha$-catenin, collagen IV and Ki-67 expression in epithelial ovarian cancer, J. Clin. Oncol. 16 (1998), 2591-2600.

[68] C. Gamallo, J. Palacios, G. Moreno, J. Calvo de Mora, A. Suarez and A. Armas, $\beta$-catenin expression pattern in stage I and II ovarian carcinomas. Relationship with $\beta$-catenin gene mutations, clinicopathological features and clinical outcome, Am. J. Pathol. 155 (1999), 527-536

[69] R.L. Giuntoli 2nd, G.C. Rodriguez, R.S. Whitaker, R. Dodge and J.A. Voynow, Mucin gene expression in ovarian cancers, Cancer Res. 58 (1998), 5546-5550.

[70] V. Mascuillo, A. Sgambato, C. Pacilio, B. Pucci, G. Ferrandina, J. Palazzo, A. Carbone, A. Cittadini, S. Mancuso, G. Scambia and A. Giordano, Frequent loss of expression of the cyclin-dependent kinase inhibitor p27 in epithelial ovarian cancer, Cancer Res. 59 (1999), 3790-3794.

[71] F. Flam, N. Einhorn and K. Sjovall, Symptomatology of ovarian cancer, Eur. J. Obstet. Gynecol. Reprod. Biol. 27 (1988), 53-57.

[72] S. Granberg, H. Noren and L. Friberg, Ovarian cancer stages I and II: Predictions and 5-year survival in two decades, $G y$ necol. Oncol. 35 (1989), 204-208.

[73] P. Holm-Nielsen, Pathogenesis of ascites in peritoneal carcinomatosis, Acta Pathol. Microbiol. Scand. 33 (1953), 10-21.

[74] K. Hirabayashi and J. Graham, The genesis of ascites in ovarian cancer, Am. J. Obstet. Gynecol. 106 (1970), 492-497.

[75] G.B. Feldman, R.C. Knapp, S.E. Order and S. Hellman, The role of lymphatic obstruction in the formation of ascites in a murine ovarian carcinoma, Cancer Res. 32 (1972), 16631666.

[76] A.J. Dembo, M. Davy, A.E. Stenwig, E.J. Berle, S.S. Bush and K. Kjorstad, Prognostic factors in patients with stage I epithelial ovarian cancer, Obstet. Gynecol. 75 (1990), 263273.

[77] F.Y. Ahmed, E. Wiltshaw, R.P. A'Hern, B. Nicol, J. Shepherd, P. Blake, C. Fisher and M.E. Gore, Natural history and prognosis of untreated stage I epithelial ovarian carcinoma, J. Clin. Oncol. 14 (1996), 2968-2975.

[78] S. Yoshimura, R.E. Scully, D.A. Bell and P.D. Taft, Correlation of ascitic fluid cytology with histologic findings before and after treatment of ovarian cancer, Am. J. Obstet. Gynecol. 148 (1984), 716-721.

[79] A.P. Makar, M. Baekelandt, C.G. Tropé and G.B. Kristensen, The prognostic significance of residual disease, FIGO substage, Tumor histology and grade in patients with FIGO stage III ovarian cancer, Gynecol. Oncol. 56 (1995), 175-180.

[80] L.E. Puls, T. Duniho, J.E. Hunter, R. Kryscio, D. Blackhurst and $\mathrm{H}$. Gallion, The prognostic implication of ascites in advanced-stage ovarian cancer, Gynecol. Oncol. 61 (1996), 109-112.

[81] S.M. Ansell, B.L. Rapoport, G. Falkson, J.I. Raats and C.M. Moeken, Survival determinants in patients with advanced ovarian cancer, Gynecol. Oncol. 50 (1993), 215-220. 
[82] G. Bolis, A. Villa, P. Guarnerio, C. Ferraris, N. Gavoni, G. Giardina, M. Melpignano, G. Scarfone, F. Zanaboni and F. Parazzini, Survival of women with advanced ovarian cancer and complete pathologic response at second look laparotomy, Cancer 77 (1996), 128-131.

[83] R.I. Demopoulos, B. Bigelow, A. Blaustein, J. Chait, E. Gutman and N. Dubin, Characterization and survival of patients with serous cystadenocarcinoma of the ovaries, Obstet. Gynecol. 64 (1984), 557-563.

[84] G.H. Eltabbakh, B.A. Werness, S. Piver and L.E. Blumenson, Prognostic factors in extraovarian primary peritoneal carcinoma, Gynecol. Oncol. 71 (1998), 230-239.

[85] J. Fujimoto, S. Ichigo, R. Hirose, H. Sakaguchi and T. Tamaya, Suppression of E-cadherin and alpha- and betacatenin mRNA expression in the metastatic lesions of gynecological cancers, Eur. J. Gynaecol. Oncol. 18 (1997), 484-487.

[86] J. Fujimoto, S. Ichigo, R. Hirose, H. Sakaguchi and T. Tamaya, Expression of E-cadherin and alpha- and betacatenin mRNA in ovarian cancers, Cancer Lett. 115 (1997), 207-212.

[87] M. Inoue, H. Ogawa, M. Miyata, H. Shiozaki and T. Tanizawa, Expression of E-cadherin in normal, benign and malignant tissues of female genital organs, Am. J. Clin. Pathol. 98 (1992), 76-80.

[88] K. Sundfeldt, Y. Piontkewitz, K. Ivarsson, O. Nilsson, P. Hellberg, M. Brannstrom, P.O. Jansen, S. Enerback and L. Hedin, E-cadherin expression in human epithelial ovarian cancer and normal ovary, Int. J. Cancer 74 (1997), 275-280.

[89] Y. Abe, T. Tsutsui, J. Mu, A. Kosugi, H. Yagita, K. Sobue, O. Niwa, H. Fujiwara and T. Hamaoka, A defect in cell-tocell adhesion via integrin-fibronectin interactions in a highly metastatic tumor cell line, Jpn. J. Cancer Res. 88 (1997), 6471.

[90] T. Kishikawa, M. Sakamoto, Y. Ino, K. Kubushiro, S. Nozawa and S. Hirohashi, Two distinct patterns of peritoneal involvement shown by in vitro and in vivo ovarian cancer dissemination models, Invasion Metastasis 15 (1995), 11-21.

[91] M.J. Gardner, L.M. Jones, J.B. Catterall and G.A. Turner, Expression of cell adhesion molecules on ovarian tumor cell lines and mesothelial cells, in relation to ovarian cancer metastasis, Cancer Lett. 91 (1995), 229-234.

[92] T.L. Moser, S.V. Pizzo, L.M. Bafetti, D.A. Fishman and M.S. Stack, Evidence for preferential adhesion of ovarian epithelial carcinoma cells to type I collagen mediated by the alpha2beta1 integrin, Int. J. Cancer 67 (1996), 695-701.

[93] C.T. Yuen, A.M. Lawson, W. Chai, M. Larkin, M.S. Stoll, A.C. Stuart, F.X. Sullivan, T.J. Ahern and T. Feizi, Novel sulfated ligands for the cell adhesion molecule E-selectin revealed by the neoglycolipid technology among o-linked oligosaccharides on an ovarian cystadenoma glycoprotein, Biochemistry 31 (1992), 9126-9131.

[94] R.E. Banks, A.J. Gearing, I.K. Hemingway, D.R. Norfolk, T.J. Perren and P.J. Selby, Circulating intercellular adhesion molecule-1 (ICAM-1), E-selectin and vascular cell adhesion molecule (VCAM-1) in human malignancies, Br. J. Cancer 68 (1993), 122-124.

[95] A.P. Skubitz, R.C. Bast, Jr., E.A. Wayner, P.C. Letourneau and M.S. Wilke, Expression of alpha 6 and beta 4 integrins in serous ovarian carcinoma correlates with expression of the basement membrane protein laminin, Am. J. Pathol. 148 (1996), 1445-1461.

[96] G.G. Zhu, L. Risteli, M. Makinen, J. Risteli, A. Kauppila and F. Stenback, Immunohistochemical study of type I collagen and type I pN-collagen in benign and malignant ovarian neoplasms, Cancer 75 (1995), 1010-1017.

[97] K. Ryuko, O. Iwanari, S. Nakayama, K. Iida and M. Kitao, Clinical evaluation of serum sialosyl-Tn antigen levels in comparison with CA 125 levels in gynecologic cancers, Cancer 69 (1992), 2368-2378.

[98] D.M. Provencher, C.L. Finstad, P.E. Saigo, S.C. Rubin, W.J. Hoskins, M.G. Federici, E. Stockert, K.O. Lloyd and J.L. Lewis, Jr., Comparison of antigen expression on fresh and cultured ascites cells and on solid tumors of patients with epithelial ovarian cancer, Gynecol. Oncol. 50 (1993), 78-83.

[99] S.C. Rubin, C.L. Finstad, W.J. Hoskins, D. Provencher, M.G. Federici, K.O. Lloyd and J.L. Lewis, Jr., Analysis of antigen expression at multiple tumor sites in epithelial ovarian cancer, Am. J. Obstet. Gynecol. 164 (1991), 558-563.

[100] D.H. Moore, B. Allison, K.Y. Look, G.P. Sutton and R.M. Bigsby, Collagenase expression in ovarian cancer cell lines, Gynecol. Oncol. 65 (1997), 78-82.

[101] J.M. Liebman, P.D. Burbelo, Y. Yamada, R. Fridman and H.K. Kleinman, Altered expression of basement-membrane components and collagenases in ascitic xenographs of OVCAR-3 ovarian cancer cells, Int. J. Cancer 55 (1993), 102-109.

[102] R.S. Boyd and F.R. Balkwill, MMP-2 release and activation in ovarian carcinoma: the role of fibroblasts, Br. J. Cancer $\mathbf{8 0}$ (1999), 315-321.

[103] M. Höyhtyä, R. Fridman, D. Komarek, K. Porter-Jordan, W.G. Stetler-Stevenson, L.A. Liotta and C.M. Liang, Immunohistochemical localization of matrix metalloproteinase 2 and its specific inhibitor TIMP-2 in neoplastic tissues with monoclonal antibodies, Int. J. Cancer 56 (1994), 500-505.

[104] M. Takemura, C. Azuma, T. Kimura, T. Kanai, F. Saji and O. Tanizawa, Type-IV collagenase and tissue inhibitor of metalloproteinase in ovarian cancer tissues, Int. J. Gynecol. $\mathrm{Ob}$ stet. 46 (1994), 303-309.

[105] S. Afzal, E.N. Lalani, R. Poulsom, A. Stubbs, G. Rowlinson, H. Sato, M. Seiki and G.W.H. Stamp, MT1-MMP and MMP2 mRNA expression in human ovarian tumors. Possible implications for the role of desmoplastic fibroblasts, Hum. Pathol. 29 (1998), 155-165.

[106] S. Afzal, E.N. Lalani, W.D. Foulkes, B. Boyce, S. Tickle, M.R. Cardillo, T. Baker, M. Pignatelli and G.W.H. Stamp, Matrix metalloproteinase-2 and tissue inhibitor of metalloproteinase-2 expression and synthetic matrix metalloproteinase-2 inhibitor binding in ovarian carcinomas and tumor cell lines, Lab. Invest. 74 (1996), 406-421.

[107] M. De Nictolis, S. Garbisa, G. Lucarini, G. Goteri, L. Masiero, A. Ciavattini, G.G. Garzetti, W.G. StetlerStevenson, G. Fabris, G. Biagini and J. Prat, 72-KiloDalton type IV collagenase, type IV collagen and Ki 67 antigen in serous tumors of the ovary: A clinicopathologic, immunohistochemical and serological study, Int. J. Gynecol. Pathol. 15 (1996), 102-109. 
[108] G.G. Garzetti, A. Ciavattini, G. Lucarini, G. Goteri, M. De Nictolis, S. Garbisa, L. Masiero, C. Romanini and G. Biagini, Tissue and serum metalloproteinase (MMP-2) expression in advanced ovarian serous cystadenocarcinomas: Clinical and prognostic implications, Anticancer Res. 15 (1995), 2799-2804.

[109] M.S. Naylor, G.W. Stamp, B.D. Davies and F.R. Balkwill, Expression and activity of MMPS and their regulators in ovarian cancer, Int. J. Cancer 58 (1994), 50-56.

[110] E. Campo, M.J. Merino, F.A. Tavassoli, A.S. Charonis, W.G. Stetler-Stevenson and L.A. Liotta, Evaluation of basement membrane components and the $72 \mathrm{kDa}$ type IV collagenase in serous tumors of the ovary, Am. J. Surg. Pathol. 16 (1992), 500-507.

[111] H. Autio-Harmainen, T. Karttunen, T. Hurskainen, M. Höyhtyä, A. Kauppila and K. Tryggvason, Expression of 72 kilodalton type IV collagenase (gelatinase A) in benign and malignant ovarian tumors, Lab. Invest. 69 (1993), 312-321.

[112] C.W.M. Bedrossian, Malignant Effusions: A Multimodal Approach to Cytologic Diagnosis, Igaku-Shoin, New-York, NY, 1994.

[113] C.W.M. Bedrossian, Diagnostic problems in serous effusions, Diagn. Cytopathol. 19 (1998), 131-137.

[114] R.E. Zuna and M.L. Mitchell, Cytologic findings in peritoneal washings associated with benign geyecologic disease, Acta Cytol. 32 (1988), 139-147.

[115] R.E. Zuna, M.L. Mitchell, K.A. Mulick and W.M. Weijchert, Cytohistologic correlation of peritoneal washing cytology in gynecologic disease, Acta Cytol. 33 (1989), 327-336.

[116] E.M. Ziselman, S.E. Harkavy, M. Hogan, W. West and B. Atkinson, Peritoneal washing cytology. Uses and diagnostic criteria in gynecologic neoplasms, Acta Cytol. 28 (1984), 105-110.

[117] J.R. Covell, J.B. Carry and P.S. Feldman, Peritoneal washings in ovarian tumors. Potential sources of error in cytologic diagnosis, Acta Cytol. 29 (1985), 310-316.

[118] E. Ravinsky, Cytology of peritoneal washings in gynecologic patients. Diagnostic criteria and pitfalls, Acta Cytol. 30 (1986), 8-16.

[119] N. Sneige, T. Fernandez, L.J. Copeland and R.L. Katz, Müllerian inclusions in washings. Potential source of error in cytologic diagnosis, Acta Cytol. 30 (1986), 271-276.

[120] M.K. Sidawy and S.G. Silverberg, Endosalpingiosis in female peritoneal washings: a diagnostic pitfall, Int. J. Gynecol. Pathol. 6 (1987), 340-346.

[121] P.B. Clement and R.H. Young, Florid mesothelial hyperplasia associated with ovarian tumors: a potential source of error in tumor diagnosis and staging, Int. J. Gynecol. Pathol. 12 (1993), 51-58.

[122] A.S. Leong, R. Parkinson and J. Milios, "Thick" cell membranes revealed by immunohistochemical staining: a clue to the diagnosis of mesothelioma, Diagn. Cytopathol. 6 (1990), 9-13.

[123] J.M. Esteban, S. Yokota, S. Husain and H. Battifora, Immunocytochemical profile of benign and carcinomatous effusions. A practical approach to difficult diagnosis, Am. J. Clin. Pathol. 94 (1990), 698-705.
[124] R.J. Tickman, C. Cohen, V.A. Varma, P.S. Fekete and P.B. DeRose, Distinction between carcinoma cells and mesothelial cells in serous effusions. Usefulness of immunohistochemistry, Acta Cytol. 34 (1990), 491-496.

[125] P.W. Shield, J.J. Callan and P.L. Devine, Markers for metastatic adenocarcinoma in serous effusion specimens, $D i$ agn. Cytopathol. 11 (1994), 237-245.

[126] D.M. Frisman, W.F. McCarthy, P. Schleiff, S.B. Buckner, J.D. Nocito, Jr. and T.J. O'Leary, Immunohistochemistry in the differential diagnosis of effusions: Use of logistic regression to select a panel of antibodies to distinguish adenocarcinomas from mesothelial proliferations, Mod. Pathol. 6 (1993), 179-184.

[127] K.V. Nance and J.F. Silverman, Immunocytochemical panel for the identification of malignant cells in serous effusions, Am. J. Clin. Pathol. 95 (1991), 867-874.

[128] M. Delahaye, F. van der Ham and T.H. van der Kwast, Complementary value of five carcinoma markers for the diagnosis of malignant mesothelioma, adenocarcinoma metastasis and reactive mesothelium in serous effusions, Diagn. Cytopathol. 17 (1997), 115-120.

[129] V. Kuenen-Boumeester, P. van Loenen, E.M.C.A. de Bruijn and S.C. Henzen-Logmans, Quality control of immunocytochemical staining of effusions using a standardized method of cell processing, Acta Cytol. 40 (1996), 475-479.

[130] P. Athanassiadou, P. Athanassiades, D. Lazaris, K. Kyrkou, E. Petrakakou and D. Aravantinos, Immunocytochemical differentiation of reactive mesothelial cells and adenocarcinoma cells in serous effusions with the use of carcinoembryonic antigen and fibronectin, Acta Cytol. 38 (1994), 718-722.

[131] A.F. Lauritzen, Diagnostic value of monoclonal antibody B72.3 in detecting adenocarcinoma cells in serous effusions, APMIS 97 (1989), 761-766.

[132] R.J. Robinson and D. Royston, Comparison of monoclonal antibodies AUA1 and BER EP4 with anti-CEA for detecting carcinoma cells in serous effusions and distinguishing them from mesothelial cells, Cytopathology 4 (1993), 267-271.

[133] M.E. Bailey, R.W. Brown, D.R. Mody, P. Cagle and I. Ramzy, Ber-EP4 for differentiating adenocarcinoma from reactive and neoplastic mesothelial cells in serous effusions. Comparison with carcinoembryonic antigen, B72.3 and Leu-M1, Acta Cytol. 40 (1996), 1212-1216.

[134] J.S. Lee, J.H. Nam, M.C. Lee, C.S. Park and S.W. Juhng, Immunohistochemical panel for distinguishing between carcinoma and reactive mesothelial cells in serous effusions, Acta Cytol. 40 (1996), 631-636.

[135] M.K. Flynn, W. Johnston and S. Bigner, Carcinoma of ovarian and other origins in effusions. Immunocytochemical study with a panel of monoclonal antibodies, Acta Cytol. 37 (1993), 439-447.

[136] K.W. Matter-Walstra and R. Kraft, Atypical cells in effusions: Diagnostic value of cell image analysis combined with immunocytochemistry, Diagn. Cytopathol. 15 (1996), 263-269.

[137] B. Maguire, D. Whitaker, S. Carello and D. Spagnolo, Monoclonal antibody Ber-EP4: Its use in the differential diagnosis of malignant mesothelioma and carcinoma in cell blocks of malignant effusions and FNA specimens, Diagn. Cytopathol. 10 (1994), 130-134. 
[138] A.A. Diaz-Arias, T.S. Loy, J.T. Bickel and R.K. Chapman, Utility of Ber-EP4 in the diagnosis of adenocarcinoma in effusions: An immunocytochemical study of 232 cases, Diagn. Cytopathol. 9 (1993), 516-521.

[139] R.L. Morgan, B.R. De Young, V.R. McGaughy and T.H. Niemann, MOC-31 aids in the differentiation between adenocarcinoma and reactive mesothelial cells, Cancer. Cytopathol. 87 (1999), 390-394

[140] A. Simsir, P. Fetsch, D. Mehta, M. Zakowski and A. Abati, Ecadherin, N-Cadherin and calretinin in pleural effusions: the good, the bad, the worthless, Diagn. Cytopathol. 20 (1999), 125-130.

[141] K. Schofield, T. D'Aquila and D.L. Rimm, The cell adhesion molecule, E-Cadherin, distinguishes mesothelial cells from carcinoma cells in fluids, Cancer 81 (1997), 293-298.

[142] H. Kitazume, K. Kitamura, K. Mukai, Y. Inayama, N Kawano, N. Nakamura, J. Sano, K. Mitsui, S. Yoshida and Y. Nakatani, Cytologic differential diagnosis among reactive mesothelial cells, malignant mesothelioma and adencarcinoma: Utility of combined E-cadherin and calretinin immunostaining, Cancer Cytopathol. 90 (2000), 55-60.

[143] P.A. Fetsch, A. Abati and Y.M. Hijazi, Utility of the antibodies CA 19-9, HMBE-1 and Thrombomodulin in the diagnosis of malignant mesothelioma and adenocarcinoma in cytology, Cancer 84 (1998), 101-108.

[144] M.C.P. Barberis, M. Faleri, S. Veronese, C. Casadio and G. Viale, Calretinin. A selective marker of normal and neoplastic mesothelial cells in serous effusions, Acta Cytol. 41 (1997), 1757-1761.

[145] J. Kupryjanczyk and G. Karpinska, Desmin expression in reactive mesothelium: A potential aid in evaluation of gynecologic specimens, Int. J. Gynecol. Pathol. 17 (1998), 123-128.

[146] P.W. Shield, Lectin binding properties of cells from serous effusion and peritoneal washing specimens, J. Clin. Pathol. 42 (1989), 1178-1183.

[147] E. Rosen-Levin, J.R. Patil, C.W. Watson and J. Jagirdar, Distinguishing benign from malignant pleural effusions by lectin immunocytochemistry, Acta Cytol. 33 (1989), 499-504.

[148] J.S. Lee, M.C. Lee, C.S. Park and S.W. Juhng, Diagnostic value of $\mathrm{p} 53$ protein and flow cytometric DNA analysis in the study of serous effusions, Acta Cytol. 41 (1995), 1719-1725.

[149] J. Sikora, J. Dworacki, M. Trybus, H. Batura-Gabryel and J. Zeromski, Correlation between DNA content, expression of Ki-67 antigen of tumor cells and immunophenotype of lymphocytes from malignant effusions, Tumor Biol. 19 (1998), 196-204.

[150] M.G. Joseph, D. Banerjee, P. Harris, S. Gibson and R.G. McFadden, Multiparameter flow cytometric DNA analysis of effusions: A prospective study of 36 cases compared with routine cytology and immunohistochemistry, Mod. Pathol. 8 (1995), 686-693.

[151] H.F. Frierson, S.E. Mills and J.F. Legier, Flow cytometric analysis of ploidy in immunohistochemically confirmed examples of malignant epithelial mesothelioma, Am. J. Clin. Pathol. 90 (1988), 240-243.

[152] A. Rijken, A. Dekker, S. Taylor, P. Hoffman, M. Blank and J.R. Krause, Diagnostic value of DNA analysis in effusions by flow cytometry and image analysis, Am. J. Clin. Pathol. 95 (1991), 6-12.
[153] H. Motherby, T. Marcy, M. Hecker, B. Ross, B. Nadjari, H.A.K.M. Müller, D. Häussinger, B.E. Strauer and A. Böcking, Static DNA cytometry as a diagnostic aid in effusion cytology. I. DNA aneuploidy for identification and differentiation of primary and secondary tumors of the serous membranes, Analyt. Quant. Cytol. Histol. 20 (1998), 153-161.

[154] H. Motherby, B. Nadjari, T. Rammerbach, T. Marcy, N. Pomjanskaja, W. Müller, K. Knops, D. Häussinger, B.E. Strauer and A. Böcking, Static DNA cytometry as a diagnostic aid in effusion cytology. II. DNA aneuploidy for identification of neoplastic cells in equivocal effusions, Analyt. Quant. Cytol. Histol. 20 (1998), 162-168.

[155] J. Kaern, C.G. Tropé, G.B. Kristensen and E.O. Pettersen, Flow cytometric DNA ploidy and S-phase heterogeneity in advanced ovarian carcinoma, Cancer 73 (1994), 1870-1877.

[156] G. Haroske, F. Giroud, A. Reith and A. Böcking, 1997 ESACP consensus report on diagnostic DNA image cytometry. Part I: basic considerations and recommendations for preparation, measurement and interpretation. European Society for Analytical Cellular Pathology, Anal. Cell. Pathol. 17 (1998), 189200.

[157] F. Giroud, G. Haroske, A. Reith and A. Böcking, 1997 ESACP consensus report on diagnostic DNA image cytometry. Part II: Specific recommendations for quality assurance. European Society for Analytical Cellular Pathology, Anal. Cell. Pathol. 17 (1998), 201-208.

[158] M. Tamai, H. Tanimura, H. Yamaue, M. Iwahashi, T. Tsunoda, M. Tani, K. Noguchi, T. Hotta and K. Arii, Expression of carcinoembryonic antigen in fresh human gastric cancer cells assessed by flow cytometry, J. Surg. Oncol. 52 (1993), 176180.

[159] S. Roka, M. Fiegl, N. Zojer, M. Filipits, R. Schuster, B. Steiner, R. Jakesz, H. Huber and J. Drach, Aneuploidy of chrosome 8 as detected by interphase fluoroscence in situ hybridization is a recurrent finding in primary and metastatic breast cancer, Breast Cancer Res. Treat. 48 (1998), 125-133.

[160] N. Zojer, M. Fiegl, L. Mullauer, A. Chott, S. Roka, J. Ackermann, M. Raderer, H. Kauffman, A. Reiner, H. Huber and J. Drach, Chromosomal imbalances in primary and metastatic pancreatic carcinoma as detected by interface cytogenetics: basic findings and clinical aspects, Br. J. Cancer 77 (1998), 1337-1342.

[161] N. Zojer, M. Fiegl, J. Angerler, L. Mullauer, A. Gsur, S. Roka, M. Pecherstorfer, H. Huber and J. Drach, Interface fluorescence in situ hybridization improves the detection of malignant cells in effusions from breast cancer patients, $\mathrm{Br}$. J. Cancer 75 (1997), 403-407.

[162] M. Augustus, S. Bruderlein and E. Gebhart, Cytogenetic and cell cycle studies in metastatic cells from ovarian carcinomas, Anticancer Res. 6 (1986), 283-289.

[163] J. Musilova and K. Michalova, Cytogenetic study of cancer cells in effusions, Cancer Genet. Cytogenet. 19 (1986), 271279.

[164] S. Bruderlein and E. Gebhart, Double minutes in prematurely condensed chromatin of human tumor cells, Cancer Genet. Cytogenet. 16 (1985), 145-152.

[165] E. Gebhart, S. Bruderlein, A.H. Tulusan, K. von-Maillot and J. Birkmann, Incidence of double minutes, cytogenetic equivalents of gene amplifications, in human carcinoma cells, Int. J. Cancer 34 (1984), 369-373. 
[166] H. Engel, J. Friedrich, C. Kleespies, C.M. Kurbacher, T. Schondorf, O. Grecu, H. Kolhagen and P. Mallmann, Detection of chromosomal aberrations in tumor cells and tumor infiltrating lymphocytes by molecular cytogenetics in patients with gynecological cancer, Cancer Genet. Cytogenet. 106 (1998), 159-165.

[167] A.A. Renshaw, B.R. Dean, K.H. Antman, D.J. Sugarbaker and A.S. Cibas, The role of cytologic evaluation of pleural fluid in the diagnosis of malignant mesothelioma, Chest 111 (1997), 106-109.

[168] T.M. Johnson, D.J. Kuffel and G.W. Dewald, Detection of hyperdiploid malignant cells in pleural effusions with chromosome-specific probes and fluorescence in situ hybridization, Mayo Clin. Proc. 71 (1996), 643-648.

[169] R. Granados, E.S. Cibas and J.A. Fletcher, Cytogenetic analysis of effusions from malignant mesothelioma. A diagnostic adjunct to cytology, Acta Cytol. 38 (1994), 711-717.

[170] K. Tanaka, C.R. Boice and G.R. Testa, Chromosome aberrations in nine patients with ovarian cancer, Cancer Genet. Cytogenet. 43 (1989), 1-14.

[171] J. Sikora, G. Dworacki and J. Zeromski, DNA ploidy, S-phase and $\mathrm{Ki}-67$ antigen expression in the evaluation of cell content of pleural effusions, Lung 174 (1996), 303-313.

[172] A. El-Habashi, S.M. Freeman, B. el-Morsi, G.F. Morris and A.J. Marrogi, p53 and PCNA coexpression of 81 pleural and peritoneal specimens: an immunohistochemical study, Pathol. Res. Pract. 192 (1996), 834-839.

[173] M.S. Huang, M.S. Tsai, J.J. Hwang and T.H. Wang, Comparison of nucleolar organizer regions and DNA flow cytometry in the evaluation of pleural effusion, Thorax 49 (1994), 11521156.

[174] M. Derenzini, F. Nardi, F. Farabegoli, A. Ottinetti, F. Roncaroli and G. Bussolati, Distribution of silver-stained interphase nucleolar organizer regions as a parameter to distinguish neoplastic from non-neoplastic reactive cells in human effusions, Acta Cytol. 33 (1989), 491-498.

[175] S.M. Lim, M.A. Duggan, M. Ruff, S. Rahim, S.E. McGregor and F.H. Green, Morphometric analysis of nucleolar organizer regions in benign and malignant peritoneal washings using backscattred electron microscopy, J. Pathol. 166 (1992), 5360.

[176] R. Carillo, N. Sneige and A.K. el-Naggar, Interphase nucleolar organizer regions in the evaluation of serosal cavity effusions, Acta Cytol. 38 (1994), 367-372.

[177] G. Mantovani, A. Maccio, E. Massa, P. Lai, G. Manca, C. Mudu, R. Versace and G. Pusceddu, Relationships between Fas expression, activation molecule CD25 and functional activity of tumor-associated lymphomonocytes from neoplastic effusions, Oncol. Rep. 6 (1999), 235-239.

[178] J.A. Zoppi, E.M. Pellicer and A.S. Sundblad, Diagnostic value of p53 protein in the study of serous effusions, Acta Cytol. 39 (1995), 721-724.

[179] S.P. Dowell, E. McGoogan, S.M. Picksley, W.S. el-Deiry, B. Vogelstein and P.A. Hall, Expression of p21waf1/cip1, MDM2 and p53 in vivo: analysis of cytological preparations, Cytopathology 7 (1996), 340-351.

[180] S.P. Dowell, P.O. Wilson, N.W. Derias, D.P. Lane and P.A. Hall, Clinical utility of the immunocytochemical detection of p53 protein in cytological specimens, Cancer Res. $\mathbf{5 4}$ (1994), 2914-2918.
[181] F. Mayall, A. Heryet, D. Manga and A. Kriegeskotten, p53 immunostaining is a highly specific and moderately sensitive marker of malignancy in serous fluid cytology, Cytopathology 8 (1997), 9-12.

[182] S.S. Mullick, L.K. Green, I. Ramzy, R.W. Brown, D. Smith, M. Gondo and P.T. Cagle, p53 gene product in pleural effusions. Practical use in distinguishing benign from malignant cells, Acta Cytol. 40 (1996), 855-860.

[183] A.E. Walts, J.W. Said and H.P. Koeffler, Is immunoreactivity for p53 useful in distinguishing benign from malignant effusions? Localization of 553 gene product in benign mesothelial and adenocarcinoma cells, Mod. Pathol. 7 (1994), 462-468.

[184] A. El-Habashi, B. El-Morsi, S.M. Freeman, M. El-Didi and A.J. Marrogi, Tumor oncogenic expression in malignant effusions as a possible method to enhance cytologic diagnostic sensitivity. An immunohistochemical study of 87 cases, $A m$. J. Clin. Pathol. 103 (1995), 206-214.

[185] M.S. Tawfik and D.V. Coleman, C-myc expression in exfoliated cells in serous effusions, Cytopathology 2 (1991), 83-92.

[186] V. Ascoli, C.C. Scalzo and F. Nardi, C-erbB-2 oncoprotein immnustaining in serous effusions, Cytopathology 4 (1993), 207-218.

[187] K. Yamashita, T. Kuba, H. Shinoda, E. Takahashi and I. Okayasu, Detection of K-ras point mutations in the supernatants of peritoneal and pleural effusions for diagnosis complementary to cytologic examination, Am. J. Clin. Pathol. 109 (1998), 704-711.

[188] P.P. Athanassiadou, S.Z. Veneti, K.A. Kyrkou and P.H. Athanassiades, Detection of c-Ha-ras oncogene expression in pleural and peritoneal smear effusion by in situ hybridization, Cancer Detect Prev. 17 (1993), 585-590.

[189] C.F. Rochlitz, G.K. Scott, J.M. Dodson, E. Liu, C. Dollbaum, H.S. Smith and C.C. Benz, Incidence of activating ras oncogene mutations associated with primary and metastatic human breast cancer, Cancer Res. 49 (1989), 357-360.

[190] E. Liu, C. Dollbaum, G. Scott, C. Rochlitz, C. Benz and H.S. Smith, Molecular lesions involved in the progression of a human breast cancer, Oncogene 3 (1988), 323-327.

[191] N. Tojo, N. Inase, M. Ichioka, I. Miyazato and N. Nara, Differential expression of CD44 splice variants in malignant and benign pleural effusions, Tohoku. J. Exp. Med. 179 (1996), 273-279.

[192] D.D. Taylor, C. Gercel-Taylor and S.A.Gall, Expression and shedding of CD44 variant isoforms in patients with gynecologic malignancies, J. Soc. Gynecol. Investig. 3 (1996), 289294.

[193] A.C. Filie, A. Abati, P. Fetsch and N. Azumi, Hyaluronate binding probe and CD44 in the differential diagnosis of malignant effusions: disappointing results in cytology material, Diagn. Cytopathol. 18 (1998), 473-474.

[194] K. Matsuura, J. Kawanishi, S. Fujii, M. Imamura, S. Hirano, M. Takeichi and Y. Niitsu, Altered expression of E-cadherin in gastric cancer tissues and carcinomatous fluid, $\mathrm{Br}$. J. Cancer 66 (1992), 1122-1130.

[195] T.F. Barth, S. Bruderlein, N. Rinaldi, G. Mechtersheimer and P. Moller, Pleural mesothelioma mimics the integrin profile of activated, sessile, rather than detached mesothelial cells, Int. J. Cancer 72 (1997), 77-86. 
[196] H. Kitsuki, M. Katano, T. Morisaki and M. Torisu, CEAmediated homotypic aggregation of human colorectal cells in malignant cells in a malignant effusion, Cancer Lett. 88 (1995), 7-13.

[197] L. Mutti, A. Piacenza, V. Valenti, B. Castagneto and P.G. Betta, Expression of intercellular adhesion molecule-1 (ICAM-1) by reactive mesothelial cells in pleural effusions, Pathologica 85 (1993), 725-728.

[198] S. Koyama, T. Ebihara and K. Fukao, Expression of intercellular adhesion molecule-1 (ICAM-1) during the development of invasion and/or metastasis of gastric carcinoma, J. Cancer Res. Clin. Oncol. 118 (1992), 609-614.

[199] V. Villena, A. Lopez-Encuentra, J. Echave-Sustaeta, P. Martin-Escribano, B. Ortuno-de-Solo and J. EstenozAlfaro, Diagnostic value of CA 72-4, carcinoembryonic antigen, CA 15-3 and CA 19-9 assay in pleural fluid. A study of 207 patients, Cancer 78 (1996), 736-740.

[200] D.M. Provencher, C.L. Finstad, P.E. Saigo, S.C. Rubin, W.J. Hoskins, M.G. Federici, E. Stockert, K.O. Lloyd and J.L. Lewis, Jr., Comparison of antigen expression on fresh and cultured ascites cells and on solid tumors of patients with epithelial ovarian cancer, Gynecol. Oncol. 50 (1993), 78-83.

[201] S.C. Rubin, C.L. Finstad, W.J. Hoskins, D. Provencher, M.G. Federici, K.O. Lloyd and J.L. Lewis, Jr., Analysis of antigen expression at multiple tumor sites in epithelial ovarian cancer, Am. J. Obstet. Gynecol. 164 (1991), 558-563.

[202] D. Petrova-Skalkova, E. Krepela, D. Rasnick and J. Vicar, A latent form of cathepsin B in pleural effusions. I. Characterization of the enzyme in breast cancer patients, Biochem. Med. Metab. Biol. 38 (1987), 219-227.

[203] O. Eickelberg, C.O. Sommerfeld, C. Wyser, M. Tamm, F. Reichenberger, P.G. Bardin, M. Soler, M. Roth and A.P. Perruchoud, MMP and TIMP expression pattern in pleural effusions of different origins, Am. J. Respir. Crit. Care Med. 156 (1997), 1987-1992.

[204] A.N. Hurewitz, S. Zucker, P. Mancuso, C.L. Wu, B. Dimassimo, R.M. Lysik and D. Moutsiakis, Human pleural effusions are rich in matrix metalloproteinases, Chest 102 (1992), 1808-1814.

[205] Y. Kamiya, E. Ohmura, H. Murakami, K. Shizume, T. Tsushima, H. Demura and N. Sakuma, Transforming growth factor-alpha activity in effusions: comparison of radioimmunoassay and radioreceptorassay, Life Sci. 52 (1993), 1381-1386.

[206] A.W. Langerac, P.A. De-Laat, C.A. Van Der Linden Van Beurden, M. Delahaye, T.H. Van Der Kwast, H.C. Hoogsteden, R. Benner and M.A. Versnel, Expression of platelet-derived growth factor (PDGF) receptors in human malignant mesothelioma in vitro and in vivo, J. Pathol. 178 (1996), 151-160.

[207] V. Ascoli, C.C. Scalzo, F. Facciolo and F. Nardi, Plateletderived growth factor receptor immunoreactivity in mesothelioma and nonneoplastic mesothelial cells in serous effusions, Acta Cytol. 39 (1995), 613-622.

[208] A. Safi, M. Sadmi, N. Martinet, O. Menard, P. Vaillant, H. Gallati, M. Hosang and Y. Martinet, Presence of elevated levels of platelet-derived growth factor (PDGF) in lung adenocarcinoma pleural effusions, Chest 102 (1992), 204-207.
[209] B.K. Zebrowski, W. Liu, K. Ramirez, Y. Akagi, G.B. Mills and L.M. Ellis, Markedly elevated levels of vascular endothelial factor in malignant ascites, Ann. Surg. Oncol. 6 (1999), 373-378.

[210] A. Kraft, K. Weindel, A. Ochs, C. Marth, J. Zmija, P. Schumacher, C. Unger, D. Marmé and G. Gasti, Vascular endothelial growth factor in the sera and effusions of patients with malignant and non-malignant ascites, Cancer 85 (1999), 178187.

[211] C.T. Yang, M.H. Lee, R.S. Lan and J.K. Chen, Telomerase activity in pleural effusions: diagnostic significance, J. Clin. Oncol. 16 (1998), 567-573.

[212] V.J. Cunningham, N. Markham, A.L. Shroyer and K.R. Shroyer, Detection of telomerase expression in fine-needle aspirations and fluids, Diagn. Cytopathol. 18 (1998), 431-436.

[213] H. Gorham, K. Yoshida, T. Sugino, G. Marsh, S. Manek, M. Charnock, D. Tarin and S. Goodison, Telomerase activity in human gynecological malignancies, J. Clin. Pathol. 50 (1997), 501-504.

[214] X.C. Mu, T.P. Brien, J.S. Ross, C.V. Lowry and B.J. McKenna, Telomerase activity in benign and malignant cytologic fluids, Cancer 87 (1999), 93-99.

[215] S. Toshima, T. Arai, Y. Yasuda, T. Takaya, Y. Ito, K. Hayakawa, C. Shibuya, N. Yoshimi, M. Shibayama and Y. Kashiki, Cytological diagnosis and telomerase activity of cells in effusions of body cavities, Oncol. Rep. 6 (1999), 199203.

[216] A. Bittl, M. Nap, W. Jager, B. Lathan and N. Lang, Immunohistochemical detection of P-glycoprotein in normal and malignant tissues: a comparative study of three monoclonal antibodies, JSB-1, C219 and 265/F4, against different epitopes using frozen and paraffin tissue sections, Tumour Biol. 14 (1993), 155-166.

[217] R.E. Zuna and A. Behrens, Peritoneal washing cytology in gynecologic cancers: long-term follow-up of 355 patients, J. Natl. Cancer Inst. 88 (1996), 980-987.

[218] W.T. Creasman and F. Rutledge, The prognostic value of peritoneal cytology in gynecologic malignant disease, $\mathrm{Am}$. J. Obstet. Gynecol. 110 (1971), 773-781.

[219] B. Davidson, B. Risberg, G. Kristensen, G. Kvalheim, E. Emilsen, A. Bjåmer and A. Berner, Detection of cancer cells in effusions from patients diagnosed with gynecological malignancies - evaluation of five epithelial markers, Virchows Arch. 435 (1999), 43-49.

[220] B. Davidson, A. Berner, J.M. Nesland, B. Risberg, G.B. Kristensen, C.G. Tropé and M. Bryne, Carbohydrate antigen expression in primary tumors, metastatic lesions and serous effusions from patients diagnosed with epithelial ovarian carcinoma - evidence of up-regulated Tn and Sialyl Tn antigens expression in effusions, Hum. Pathol. 31 (2000), 1081-1087.

[221] B. Davidson, W.H. Gotlieb, G. Ben-Baruch, J. Kopolovic, I. Goldberg, J.M. Nesland, A. Berner, A. Bjåmer and M. Bryne, Expression of carbohydrate antigens in advanced-stage ovarian carcinomas and their metastases - a clinicopathologic study, Gynecol. Oncol. 77 (2000), 35-43.

[222] B. Davidson, A. Berner, J.M. Nesland, B. Risberg, H.S. Berner, C.G. Tropé, G.B. Kristensen, M. Bryne and V.A. Flørenes, E-cadherin and $\alpha$-, $\beta$ - and $\gamma$-catenin protein expression is up-regulated in ovarian carcinoma cells in serous effusions, J. Pathol. 192 (2000), 460-469. 
[223] B. Davidson, W.H. Gotlieb, G. Ben-Baruch, J.M. Nesland, M. Bryne, I. Goldberg, J. Kopolovic and A. Berner, E-cadherin complex protein expression and survival in ovarian carcinoma, Gynecol. Oncol. 79 (2000), 362-371.

[224] B. Davidson, R. Reich, A. Berner, V. Givant, I. Goldberg, B. Risberg, G.B. Kristensen, C.G. Tropé, M. Bryne, J. Kopolovic and J.M. Nesland, Ovarian carcinoma cells in serous effusions show altered MMP-2 and TIMP-2 mRNA levels, Eur. J. Cancer 37 (2001), 2040-2049.

[225] B. Davidson, I. Goldberg, A. Berner, J.M. Nesland, V. Givant, M. Bryne, B. Risberg, G.B. Kristensen, C.G. Tropé, J. Kopolovic and R. Reich, Expression of membrane-type 1,2 and 3 matrix metalloproteinases (MT1-MMP, MT2-MMP, MT3-MMP) mRNA in ovarian carcinoma cells in serous effusions, Am. J. Clin. Pathol. 115 (2001), 517-524.

[226] B. Davidson, I. Goldberg, W.H. Gotlieb, J. Kopolovic, G. Ben-Baruch, J.M. Nesland, A. Berner, M. Bryne and R. Reich, High levels of MMP-2, MMP-9, MT1-MMP and TIMP-2 mRNA correlate with poor survival in ovarian carcinoma, Clin. Exp. Metastas. 17 (1999), 799-808.

[227] Z. Werb, ECM and cell surface proteolysis: Regulating cellular ecology, Cell 91 (1997), 439-442.

[228] H.C. Crawford and L.N. Matrisian, Tumor and stromal expression of matrix metalloproteinases and their role in tumor progression, Invasion Metastasis 14 (1994-5), 234-245.

[229] B. Davidson, I. Goldberg, J. Kopolovic, L. Lerner-Geva, W.H. Gotlieb, G. Ben-Baruch and R. Reich, MMP-2 and TIMP-2 expression correlates with poor prognosis in cervical carcinoma - A clinicopathologic study using immunohistochemistry and mRNA in situ hybridization, Gynecol. Oncol. 73 (1999), 372-382.

[230] J.I. Risinger, A. Berchuck, M.F. Kohler and J. Boyd, Mutations of the E-cadherin gene in human gynecologic cancers, Nat. Genet. 7 (1994), 98-102.
[231] C. Gamallo, J. Palacios, G. Moreno, J. Calvo de Mora, A. Suarez and A. Armas, $\beta$-catenin expression pattern in stage I and II ovarian carcinomas. Relationship with $\beta$-catenin gene mutations, clinicopathological features and clinical outcome, Am. J. Pathol. 155 (1999), 527-536.

[232] B. Davidson, R. Reich, I. Goldberg, W.H. Gotlieb, J. Kopolovic, A. Berner, G. Ben-Baruch, M. Bryne and J.M. Nesland, Ets-1 mRNA expression is a novel marker of poor survival in ovarian carcinoma, Clin. Cancer Res. 7 (2001), 551-557.

[233] I. Goldberg, B. Davidson, R. Reich, W.H. Gotlieb, G. BenBaruch, M. Bryne, A. Berner, J.M. Nesland and J. Kopolovic, $\alpha \mathrm{V}$ integrin is a novel marker of poor prognosis in advancedstage ovarian carcinoma, Clin. Cancer Res. 7 (2001), 40734079.

[234] H.S. Berner, B. Davidson, A. Berner, B. Risberg, G.B. Kristensen, C.G. Tropé, G. Van de Putte and J.M. Nesland, Upregulation of CD44s, but not of CD44v3-10, in ovarian carcinoma cells in malignant effusions, Clin. Exp. Metastas. 18 (2000), 197-202.

[235] B. Davidson, R. Reich, J. Kopolovic, A. Berner, J.M. Nesland, G.B. Kristensen, C.G. Tropé, M. Bryne, B. Risberg, G. van de Putte and I. Goldberg, Interleukin-8 and vascular endothelial growth factor mRNA levels are down-regulated in ovarian carcinoma cells in serous effusions, Clin. Exp. Metastas. (in press).

[236] B. Davidson, P. Lazarovici, A. Ezersky, J.M. Nesland, A. Berner, B. Risberg, C.G. Tropé, G.B. Kristensen, M. Goscinski, G. van de Putte and R. Reich, Expression levels of the NGF receptors TrkA and p75 in effusions and solid tumors of serous ovarian carcinoma patients, Clin. Cancer Res. 7 (2001), 3457-3464. 


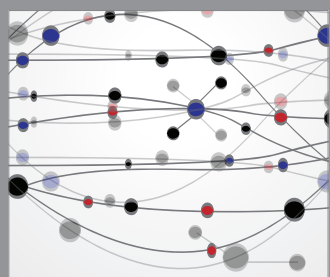

The Scientific World Journal
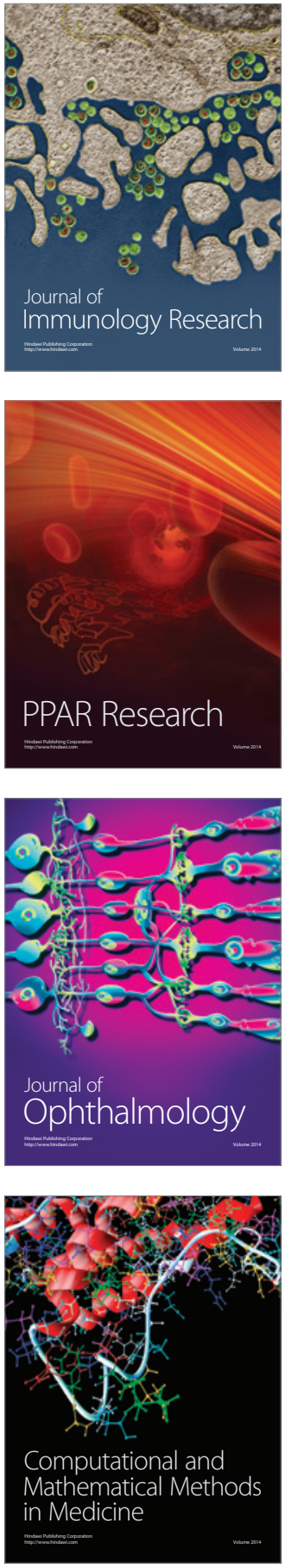

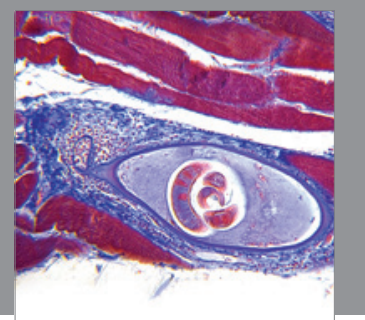

Gastroenterology

Research and Practice
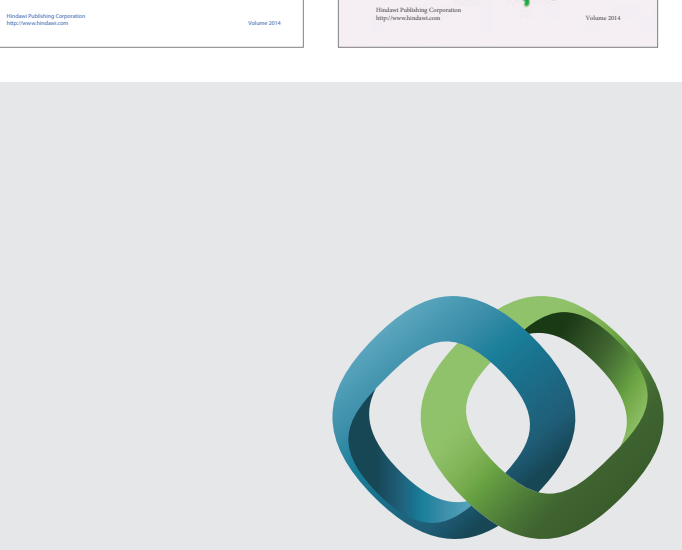

\section{Hindawi}

Submit your manuscripts at

http://www.hindawi.com
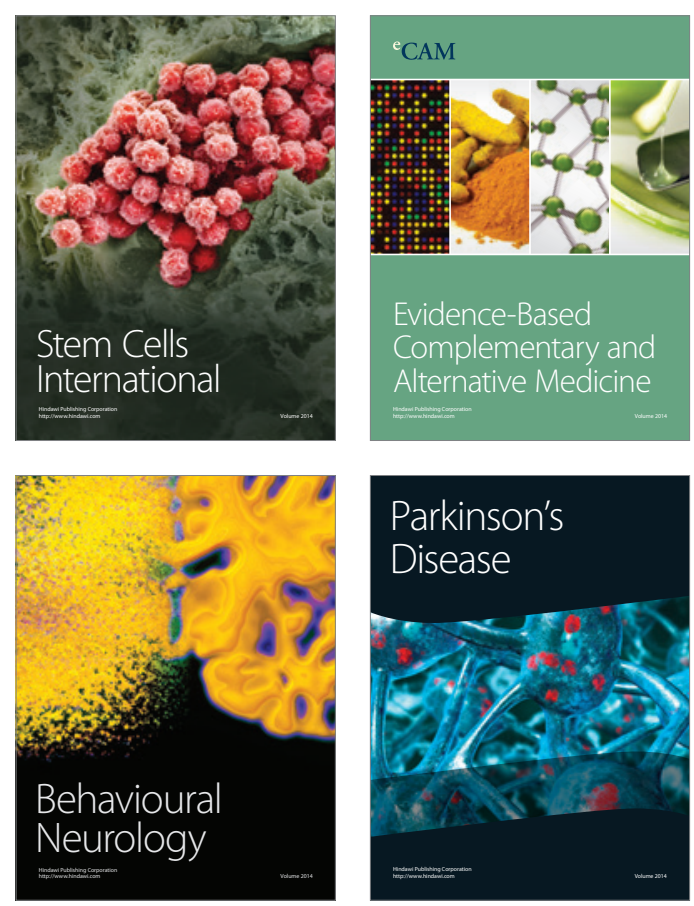

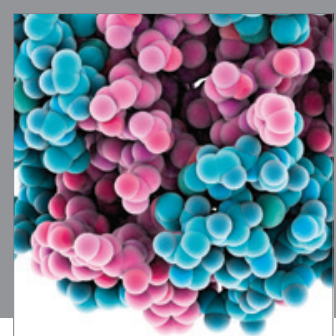

Journal of
Diabetes Research

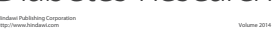

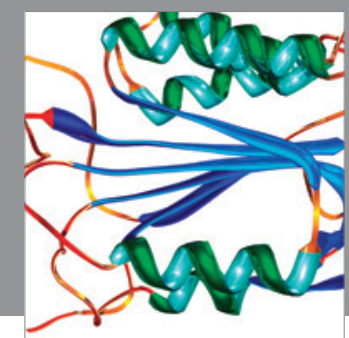

Disease Markers
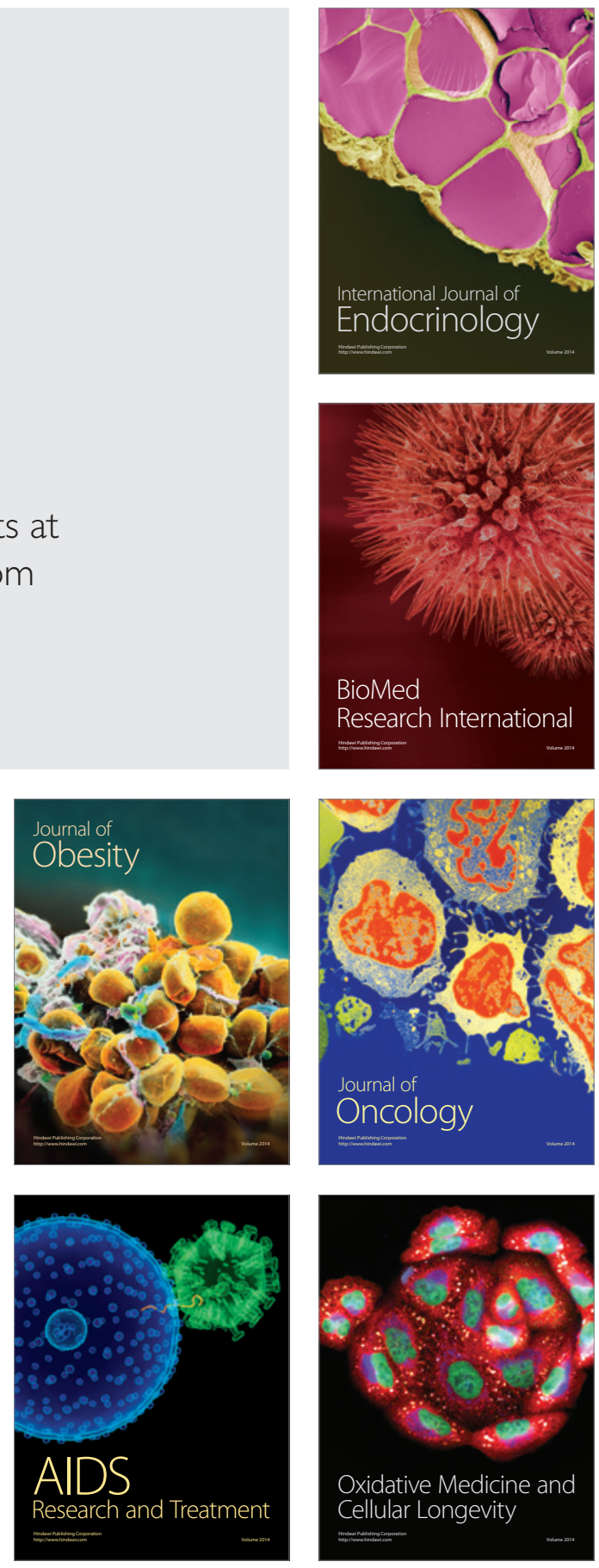